\title{
Analysis of candidate genes of QTL and chromosomal regions for essential hypertension in the rat model
}

\author{
Lishi Wang $^{1,2}$, Jiaqian Zhu ${ }^{1,3}$, Yue Huang ${ }^{1}$, Qing Xiong ${ }^{4}$, Cong-Yi Wang ${ }^{5}$, Arnold Postlethwaite ${ }^{6}$, \\ Yongjun Wang ${ }^{7}$, Weikuan $\mathrm{Gu}^{{ }^{*}}$ \\ ${ }^{1}$ Departments of Orthopaedic Surgery-Campbell Clinic and Pathology, University of Tennessee Health Science Center (UTHSC), \\ Memphis, USA \\ ${ }^{2}$ Department of Basic Medicine, Inner Mongolia Medical University, Huhhot City, China \\ ${ }^{3}$ Rust College, Holly Spring, USA \\ ${ }^{4}$ Department of Biostatistics and Bioinformatics, Duke University, Durham, USA \\ ${ }^{5}$ Center for Biotechnology and Genomic Medicine, Medical College of Georgia, Augusta, USA \\ ${ }^{6}$ Department of Medicine, University of Tennessee Health Science Center (UTHSC), Memphis, USA \\ ${ }^{7}$ Department of Neurology, Beijing Tiantan Hospital, Capital University of Medical Sciences, Beijing, China \\ Email: Lwang37@uthsc.edu, Jzhu@,rustcollege.edu, hyue@uthsc.edu, qxiong1@uthsc.edu, cwang@mail.mcg.edu, \\ apostlet@uthsc.edu, yongjunwang111@yahoo.com.cn, wwgu@uthsc.edu
}

Received 20 May 2012; revised 25 June 2012; accepted 10 July 2012

\begin{abstract}
This is an in silico analysis of quantitative trait loci (QTLs), genes, polymorphisms, and chromosomal regions regulating hypertension in the rat genome. Utilizing PGmapper, a program that matches phenoltypes to genes, we identified 266 essential hypertension-associated genes (HyperA), and 83 of these genes contain known hypertension-associated polymorphisms (HyperAP). The majority of HyperAP have been reported in recent years. Surprisingly, only a few of these HyperAP genes have been investigated for their candidacy as the QTL for hypertension. The frequency of candidate genes within peak regions of the QTL is higher than the rest of the QTL region. We also found that QTL located in both gene-rich regions and gene-rich chromosomes contained the most candidate genes. However, the number of candidate genes within a peak region is not associated with the number of total genes in a QTL region. This data could not only facilitate a more rapid and comprehensive identification for the causal genes underlying hypertension in rats, but also provides new insights into genomic structure in regulation of hypertension.
\end{abstract}

Keywords: Chromosome; Hypertension; QTL; Gene; Polymorphism; Rat

\section{INTRODUCTION}

Blood pressure and hypertension in humans are quantitative traits controlled by many genes [1-3]. Because of the

*Corresponding author. difficulties in studying genetic variations relating to hypertension in humans, researchers chose the rat as an ideal model. In recently review articles, progress for the genetic dissection of essential hypertension in humans using a rat model have been summarized. Cowley [5] pointed out that the next daunting task is gene identification and validation.

Currently, more than 300 Quantitative trait loci (QTLs) for blood pressure and hypertension are reported in the rat genome (see the Rat Genome Database web site at: http://rgd.mcw.edu/), and these QTLs are found in every rat chromosome [6]. More than 200 candidate genes relating to hypertension have been identified in rats and some of them, such as Kcnj1 and Drd2, are positioned within a QTL $[7,8]$. Most of these identified genes are relatable to human chromosomes. However, further analysis on the relationship between these candidate genes and their likelihood for being genes involved in the QTLs for hypertension will enhance the identification of the real causal genes responsible for QTLs.

In addition to just simply further analysis, more questions need to be answered in the investigation for the candidate genes responsible for the hypertension QTLs. There are three main questions that need answering: Do these candidate genes include all the genes affecting blood pressure and hypertension? How many candidate genes are within the hypertension QTLs and how close are these genes to peak markers? What is a candidate gene's relative potential candidacy for being a gene truly responsible for the QTL? The third question is the most important of the three and needs a definitive answer. Currently, due to the combination of rapidly developed genome sequence information and online literature, it is 
now possible to pinpoint accurately genes within a QTL and evaluate them much more efficiently.

\section{MATERIALS AND METHODS}

\subsection{Software}

In this investigation, we used our recently developed software named PGMapper

(http://www.genediscovery.org/pgmapper/index.jsp) to systematically examine the candidate genes for the hypertension QTLs across the whole rat genome [9]. PGMapper identified all the possible candidate genes for the hypertension QTL by combining the mapping information from Ensemble database, updated literature information from PubMed, and the Online Medelian Inheritance in Man (OMIM) database.

\subsection{Collection of QTL Loci}

We first selected blood pressure as a trait to pick up all of the possible hypertension QTLs from the Rat Genome Database (RGD, http://rgd.mcw.edu/). We then selected all the QTL that have a logarithm of odds (LOD) score $>$ 2.8. This selection criterion was based on accepted linkage criteria. A LOD score of $>4.3$ was considered significant while a LOD score between 2.8 and 4.3 was considered suggestive for linkage [10,11]. If two QTL were overlapped and connected, we analyzed them independently. However, if one QTL is located within another QTL, we just used the QTL with the larger genome size.

\subsection{Examination of Candidate Genes}

We used flanking markers to search candidate genes for QTLs that are fine-mapped and well-defined. If a flanking marker has no sequence location on Ensemble database, we used either nearby markers or markers at the peak region of the QTL (according to the curve of the LOD score). If a marker in the peak region of the QTL was used, we searched candidate genes using genomic regions of 20,000,000 base pairs (bp) on each side of the peak marker.

After we searched for candidate genes using PGMapper, visual examination of these selected candidate genes was conducted to determine the potential of each individual gene involved. First, the genes full names were checked to ensure their abbreviations. Next, at least one abstract per gene from the PGMapper's report detailing each selected gene was read to determine the candidacy of that gene. In the majority of cases, more than one abstract was read to confirm the importance of that gene.

In order to discern whether any of these candidate genes had been investigated for their candidacy in the hypertension QTL, we conducted a separate literature search on PubMed using the key words "QTL + hypertension + 'gene name'." We then read the associated literature from this search to determine any connection between our preliminary candidate genes from PGMapper and essential hypertension. A gene is considered an essential hypertension-associated gene if it is associated with essential hypertension in at least one of the following studies: 1) functional studies (i.e., knockouts, transgenics, mutagenesis, RNA interference, etc.); 2) association studies; 3) clinical studies.

In case any genes associated to essential hypertension by association studies resulted in an inconclusive result, we excluded these genes from our candidate gene list.

Candidate genes were examined whether they have been studied in the human population previously and their polymorphisms have been linked with hypertension. The key words used in our search were "hypertension and polymorphism". Thus, only when both hypertension and polymorphism appear in the same abstracts with a gene name will PGMapper collect it into our list of genes needing further review.

\subsection{Analysis of Gene Chromosomal Position and Their Candidacy}

We also searched for candidate genes within $1.5 \mathrm{cM}$ regions from the peak marker in a QTL by PGMapper. These results indicated the importance of each selected candidate genes in the QTL.

Total genomic bps within a QTL region were determined by subtracting the nucleotide base position of the right flanking marker from the position of left flanking marker. Bps per gene of a QTL region were calculated by dividing the total bps of a QTL region by the total genes according to data from Ensembl (bps per gene = total bps/total genes). Bps per candidate gene of a QTL region were calculated by dividing the total bps of a QTL region by the number of candidate genes determined from our aforementioned methods (bps per candidate gene $=$ total bps/total candidate genes) .

Gene-rich and gene-poor regions on chromosomes were determined by comparison of the bps per gene in a QTL region or chromosome. $\mathrm{P}$ values were determined using student's $t$ test. $\mathrm{R}$ values of correlation analysis were obtained with Excel.

\section{RESULTS}

\subsection{QTL and Their Candidate Genes}

The 62 hypertension QTLs cover 2,015,062,129 bp genomic sequences, which is roughly $73 \%$ of the total rat genome. Every autosomal and the $\mathrm{X}$ chromosome, except chromosomes 19 and Y (Table 1), contain at least one 
Table 1. QTL and candidate genes identified from rat model.

\begin{tabular}{|c|c|c|c|c|c|c|c|}
\hline Chromosomes & QTLs & Total genes & Length (bp) & $\begin{array}{l}\text { Hypertension } \\
\text { candidate genes }\end{array}$ & $\begin{array}{l}\text { Essential hypertension } \\
\text { associated genes }\end{array}$ & $\begin{array}{l}\text { Hypertension- } \\
\text { associated } \\
\text { polymorphisms }\end{array}$ & $\begin{array}{c}\text { Candidates } \\
\text { within } 1.5 \mathrm{cM}\end{array}$ \\
\hline $\mathrm{X}$ & 2 & 454 & $48,888,222$ & 5 & 4 & 0 & 1 \\
\hline 1 & 8 & 3419 & $247,322,280$ & 75 & 63 & 22 & 1 \\
\hline 2 & 5 & 1852 & $256,217,383$ & 44 & 12 & 4 & 1 \\
\hline 3 & 4 & 1706 & $178,038,027$ & 25 & 16 & 2 & 3 \\
\hline 4 & 4 & 1006 & $129,644,537$ & 22 & 16 & 3 & 3 \\
\hline 5 & 3 & 1562 & $151,887,861$ & 20 & 17 & 7 & 0 \\
\hline 6 & 2 & 1087 & $121,776,584$ & 18 & 14 & 8 & 0 \\
\hline 7 & 4 & 1037 & $109,297,243$ & 22 & 16 & 2 & 2 \\
\hline 8 & 3 & 1111 & $12,479,341$ & 15 & 13 & 1 & 0 \\
\hline 9 & 2 & 568 & $71,306,988$ & 13 & 10 & 2 & 1 \\
\hline 10 & 3 & 1502 & $89,111,128$ & 26 & 22 & 6 & 0 \\
\hline 11 & 2 & 569 & $71,856,931$ & 5 & 3 & 1 & 0 \\
\hline 12 & 2 & 714 & $72,770,456$ & 12 & 11 & 3 & 1 \\
\hline 13 & 4 & 745 & $87,298,215$ & 15 & 15 & 10 & 0 \\
\hline 14 & 2 & 459 & $56,035,440$ & 9 & 7 & 5 & 1 \\
\hline 15 & 3 & 192 & $54,324,114$ & 1 & 0 & 0 & 1 \\
\hline 16 & 1 & 400 & $41,833,193$ & 6 & 6 & 1 & 2 \\
\hline 17 & 3 & 757 & $87,545,639$ & 6 & 6 & 1 & 1 \\
\hline 18 & 3 & 657 & $81,554,492$ & 10 & 10 & 3 & 1 \\
\hline 20 & 2 & 469 & $45,874,055$ & 6 & 5 & 2 & 2 \\
\hline Total & 62 & 20,266 & $2,015,062,129$ & 355 & 266 & 83 & 21 \\
\hline
\end{tabular}

hypertension QTL. The genomic size of these QTL ranges from $5,873,857 \mathrm{bps}$ to $167,769,667 \mathrm{bps}$. Within the 2,015,062,129 bp genomic sequences, a total of 20,266 genes have been located. The number of genes within a QTL region ranges from 79 to 1398 . The average gene density throughout the whole rat genome (excluding $\mathrm{ChrY}$ ) is about one gene per 99,918 bp. Within the total 2,015,062,129 bp genomic sequences representing the hypertension QTL, there are roughly one gene per $99,430 \mathrm{bp}$, which is similar to the average gene per bp ratio found in the rat genome. From the total 20,266 genes related to hypertension, 266 were selected as candidate genes for essential hypertension (Table 1). Basically, about one candidate gene was chosen per 76 selected genes. These 266 candidate genes are located throughout all autosomal and X chromosomes excluding chromosome 15 (which contains no obvious recognizable candidate genes), chromosome 19, and chromosome Y.

The number of candidate genes within a QTL region can be as low as zero to as high as 32 . The number of QTL on each individual chromosome varies from one to five. There is a positive correlationship between the number of QTL on a chromosome to the number of candidate genes on a chromosome $(\mathrm{R}=0.787)$.

\subsection{Essential Hypertension Associated (HyperA) Candidate Genes and Essential Hypertension Associated Gene Polymorphisms (HyperAP)}

While the majority of candidate genes have been reported or listed in rat genome databases, we identified many new candidate genes during our search. Particularly, we have identified 83 polymorphic genes with publicized linkage to human hypertension (HyperAP). While HyperA genes are found on every chromosome containing one or more QTL regions, HyperAP genes are found only on autosomal chromosomes containing QTL regions.

In general, the number of HyperA genes is positively correlated to the number of HyperAP genes (Figure 1). Chromosome 1 has the largest number of HyperA genes and, consequentially, the largest number of HyperAP genes too. For instance, Chromosome $\mathrm{X}$ has a small number of HyperA genes and, therefore, does not have any HyperAP genes.

Surprisingly, in spite of demonstrated linkage between the polymorphic HyperAP genes and hypertension, the candidacy for the majority of these genes for hypertension QTL has not been investigated. Examples of the few 
HyperAP genes investigated, with positive or negative results, are monocyte chemotactic protein-1 (CCL2), nitric oxide synthase $2 \mathrm{~A}$ (NOS2), and natriuretic peptide precursor B (NPPB). A study identifying candidate genes for the QTL influencing blood pressure within Chr10 reported that the expression levels of CCL2 mRNA showed no difference between the kidneys of Dahl salt-sensitive (DS) and Lewis (LEW) rats fed a normal diet. However, CCL2 mRNA expression levels in DS were 10-fold higher than those in LEW with a high-salt diet [12]. Yet another study reported that NOS2 is not supported as a candidate for the QTL capable of causing a blood pressure difference between the $\mathrm{S}$ and MNS rats [13]. Nevertheless, it was suggested that the nitric oxide system appears to be secondarily involved in the regulation of blood pressure in the $\mathrm{S}$ rat, as evidenced by physiological data. In a study using a congenic approach with a rat model, the relationship between natriuretic peptide precursor A (NPPA) and NPPB genes and hypertension was examined, but an association between the NPPB gene and blood pressure was not found [14].

\subsection{Candidate Genes for the QTL on Gene-Rich and/or Gene-Poor Chromosomes}

We found that gene density for QTL on different chromosomes varies significantly. QTLs on two chromosomes are located in gene-rich regions. These two chromosomes are chromosome 1 (one gene per 72,337 bp) and chromosome 10 (one gene per 59,328 bp). However, QTLs on chromosome 15 reside in extremely gene-poor regions (one gene per 282,938 bp). The other QTLs in gene-poor regions are on chromosome 11 (one gene per 130,000 bp) (Figure 2).

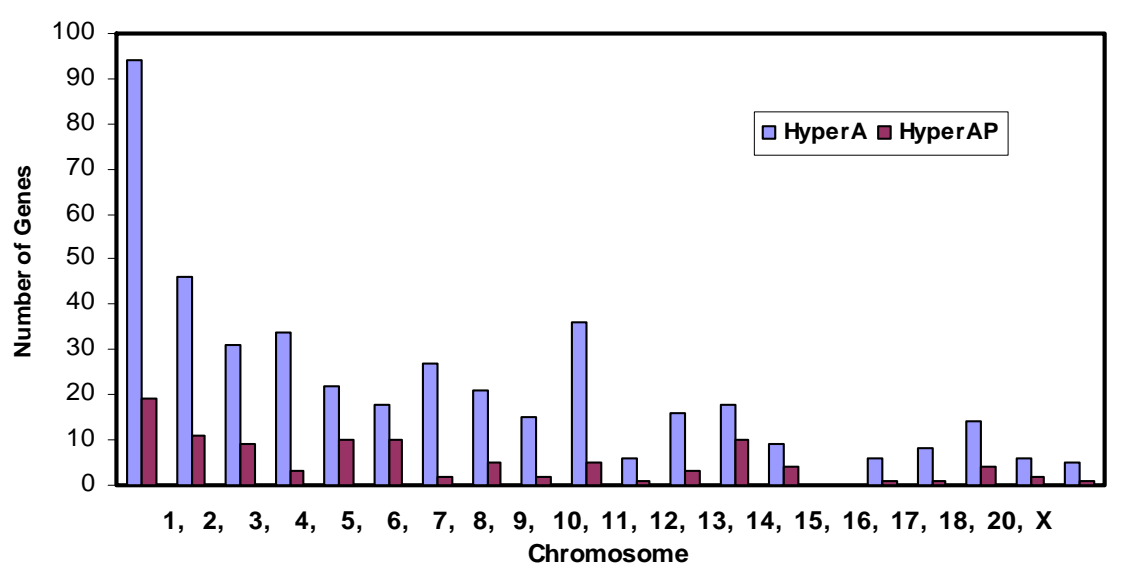

Figure 1. Number of essential hypertension associated genes (HyperA) and genes of polymorphic associated to essential hypertension in human population (HyperAP) in QTL regions on chromosomes.

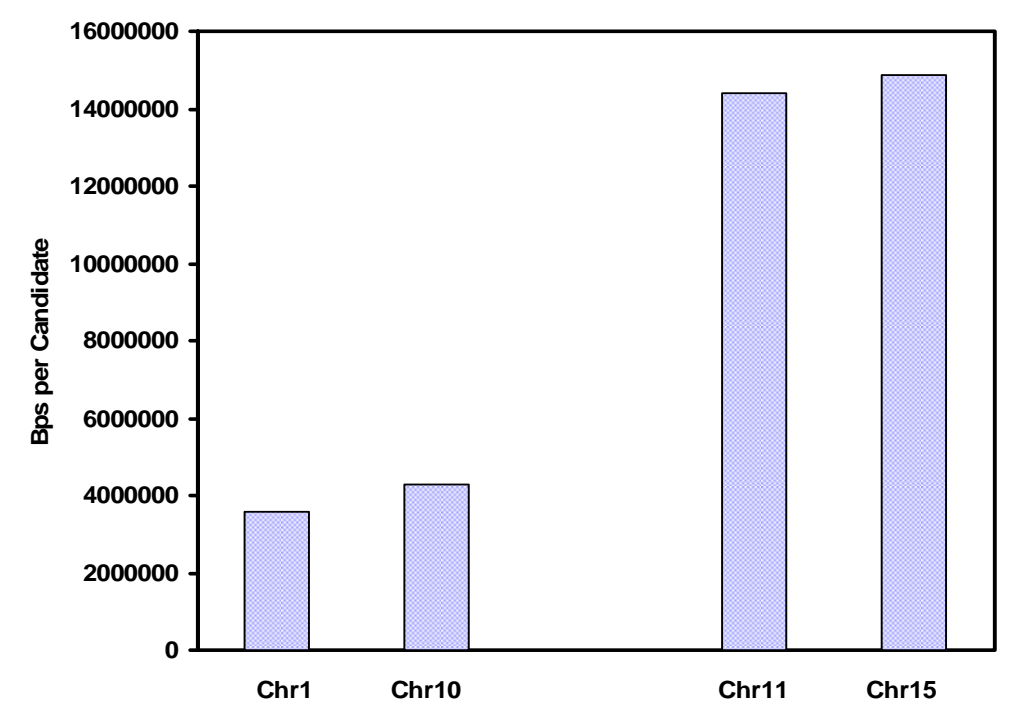

Figure 2. Number of candidate genes in QTL of gene rich chromosomes and gene poor chromosomes. 


\subsubsection{Chromosome 1}

There are 6 QTLs that overlap and cover a large proportion of this chromosome. These QTL are Bp95, Bp96, Bp173, Bp196, Bp 255, and Bp259 (Supplementary Table 1). These QTL extend from $90,448,902$ to $247,322,280$ with a length of $156,873,379$ bps. All of these QTL are located in gene-dense regions. Gene densities in four of these loci are relatively high.

The first QTL, Bp95, is in the proximal region of this chromosome, and is located in the interval from $0 \mathrm{bp}$ to $22,869,052 \mathrm{bp}$. This region contains 248 genes and four candidate genes (Table 1). Among them, transforming growth factor beta 1 (TGF-beta 1) is a fibrogenic cytokine implicated in hypertension in African-Americans. Suthanthiran et al. [15] demonstrated that AfricanAmericans with end-stage renal disease (ESRD) have higher circulating levels of TGF-beta 1 protein compared to Caucasians with ESRD. They have also found that hyperexpression of TGF-beta 1 is more frequent in African-Americans with hypertension than in Caucasians. Accordingly, they proposed that TGF-beta 1 hyperexpression may be an important mediator of hypertension and hypertensive nephrosclerosis. More recently, and importantly, polymorphisms in TGF-beta 1 have been associated with cardiovascular and renal damage. This data strongly suggests that TGF-beta 1 is the causal gene for this QTL. The other noteworthy gene in this QTL is osteoglycin (OGN). In a quantitative trait transcript (QTT) analysis study of the cardiac transcriptome in the rat, Petretto et al. [16] showed that OGN is a key regulator of left ventricular mass (LVM) in rats, mice and humans, and suggested that OGN modifies the hypertrophic response to extrinsic factors such as hypertension and aortic stenosis.

QTL Bp96 overlaps and is connected to Bp95. Bp96 covers a region from $22,842,962$ to $102,532,417 \mathrm{bps}$ and contains more than 1000 genes. Twenty genes were regarded as candidate genes. Among these 20 genes, polymorphisms in at least five of them have been linked to hypertension in human populations. TGF-beta 1 is also among these candidates. The other important gene in this group is Apolipoprotein E (APOE) [17]. Associations between polymorphisms of APOE and hypertension have been extensively studied in several countries and different populations. However, the results are sometimes controversial and vary from population to population. Kcnj11 is another gene shown to be associated with hypertension in humans [18]. Specifically, there is significant evidence linking polymorphisms of Kcnj11 to blood pressure variations in Korean [18] and Japanese [19] populations. In addition, SNPs in the renal glomerulus-specific cell adhesion receptor (Nphs1) have known associations with hypertension in the Japanese population [20]. Glucocorticoid-regulated kinase (SGK1) also has a demonstrated relationship with hypertension in populations specifically those in Germany [21] and Switzerland [22]. The Organic Cation Transporter 2, OCT2 (SLC22A2), implicated in both renal dopamine handling as well as the inactivation of circulating catecholamines, is also thought to be involved in blood pressure regulation [23].

Two QTL, Bp173 and Bp196, largely overlap each other and occupy the genome regions of $115,946,375 \mathrm{bp}$ to $189,900,838 \mathrm{bp}$ and $119,780,561 \mathrm{bp}$ to $204,280,279 \mathrm{bp}$, respectively. From the more than 1200 known genes within these two QTL, a total of 33 candidate genes were found (Supplementary Table 1). Ten of these 33 genes have been linked to hypertension in humans by polymerphic analysis. Those genes are the following: 1) Neurotrophic tyrosine kinase, receptor, type 3 (Ntrk3), a gene studied in the Japanese population [20]; 2) Prolylcarboxypeptidase (Prcp) D allele, which is coupled to chronic hypertension and associated with a significant increased risk of preeclampsia in both African-American and non-African-American women [24]; 3) Sodium channel gamma subunit gene (SCNN1G), multiple polymorphisms in human epithelial SCNN1G are associated with essential hypertension in several populations [25-27]; 4) Calpain-5 (Capn5), Capn5 variants are associated with diastolic blood pressure and cholesterol levels in the Spanish population [28]; 5) Solute Carrier family 9 member 2 (SLC9A2), Uromodulin (UMOD), and Elastin (ELN), five polymorphisms in these 3 genes were associated with hypertension status [29]; 6) Uncoupling protein 2 (Ucp2), a common polymorphism of this gene is associated with hypertension in the Japanese population [30,31]; 7) Inositol polyphosphate phosphatase-like 1 (INPPL1 and SHIP2), variants of these genes affect essential hypertension [32]; 8) Purinergic receptor p2y, g protein-coupled, 2 (P2ry2), P2ry2 is among 61 non-synonymous polymorphisms of 41 hypertension candidate genes with blood pressure variation in the Japanese population [19]; 9) SCNN1B, this gene has shown a modest-sized but highly significant effect on common genetic variation in SCNN1B on plasma potassium [33]. Interactions between the rs889299 SNP and functional SNPs in other genes influencing aldosterone-responsive distal tubular electrolyte transport may be important in the etiology of essential hypertension; 10) Spontaneously hypertensive rat-clone A-hypertension-associated gene (SAH), SAH has been extensively investigated and its gene variants are associated with obesity-related hypertension in Caucasians [34,35].

Among these 33 candidates, only two genes have been studied for their role as the QTL for hypertension. ApoE was investigated by Yuan et al. [36], and Okuda et al. [37] found that the expression of SAH has been increased in genetic hypertensive rats via microarray analysis. 
The next pair of QTL are Bp255 and Bp259. These two QTL overlap in the region from 195,927,908 bp to 247,322,280 bp. Within these two QTL, 20 candidate genes were identified. However, polymorphisms of only two of these genes (CPT1A and RGS20/GNA14) have been linked to hypertension. Carnitine palmitoyltransferase 1A (CPT1A) is among four genes that have their polymorphisms associated with left ventricular hypertrophy (LVH) in essential hypertension [38]. In "The Millennium Genome Project for Hypertension", Kohara et al. [39] found the genes RGS20 and GNA14. Dominant models for these minor alleles had significant association with hypertension in the Japanese population.

\subsubsection{Chromosome 10}

There are 3 overlapping QTLs (Bp57, Bp168, and Bp186) that cover a large proportion of this chromosome (Supplementary Table 1). All of these QTL are located in gene-dense regions.

Bp57 covers the genome region from 21,607,720 to $84,443,858$ bps. The genome region contains a total of 1026 genes and has an average of one gene per 61,243 bps. A total of 11 candidate genes were identified from this QTL, which is basically one candidate gene per 93 selected genes. From these 11 candidate genes, the five genes that were of special interest were NOS2, CCL2, 12(s)-HETE and ALOX12, and CIAS1.

Studying the ratio of circulating nitric oxide to endothelin-1 in patients with both systemic sclerosis (SSc) and pulmonary arterial hypertension (PAH), Kawaguchi et al. linked polymorphisms of the nitric oxide synthase 2 (NOS2) gene to susceptibility of both PAH and SSc in the Japanese population [40].

Chemokine, cc motif, ligand 2 (CCL2) has shown a significant and independent association between the $-2518 \mathrm{G} / \mathrm{A}$ polymorphism of the MCP-1 gene (presence of $\mathrm{G}$ allele) and hypertension in the Tunisian population [41].

The arachidonic acid-derived metabolite 12-(S) hydroxyeicosatetraenoic acid (12(S)-HETE), catalyzed by 12-lipoxygenase (12-LOX, ALOX12), exhibits a variety of biological activities with implications in cardiovascular disease. In a study of 200 patients with essential hypertension (aged $56 \pm 1$ years, mean \pm s.e.m., including 97 males) and 166 matched controls (aged $54 \pm 1$ years, 91 males), Quintana et al., [42] found that a non-synonymous polymorphism in ALOX12 is associated with both essential hypertension and urinary levels of 12(S)-HETE.

An intronic variable number of tandem repeat polymorphisms in the cold-induced autoinflammatory syndrome 1 (CIAS1) gene modifies gene expression, and is associated with essential hypertension in the Japanese population [43]. Timasheva et al. [44] found that carriers of the IL12B $1159 * \mathrm{~A} / * \mathrm{~A}$ genotype have a lower risk of stroke during a study to reveal the association of interleukin-6, interleukin-12, and interleukin-10 gene polymorphisms with essential hypertension, and its clinical complications in a Tatar ethnic group from Bashkortostan, Russia.

Bp168, overlaps Bp57 and covers a region from $27,184,742$ bp to $102,587,587 \mathrm{bp}$ and has a total of 1398 genes, which is roughly one gene per 53,936 bps. From these genes, 20 were found to be candidate genes for hypertension, and eight of these 20 genes, including NOS2, CCL2, ALOX12, are also found in Bp57. On average, every 3,770,142 bp within Bp168 has one candidate gene. Also, from these 20 genes Angiotensin Converting Enzyme (ACE) is a promising candidate gene for essential hypertension $(\mathrm{EH})$ as it plays a key role in blood pressure regulation. ACE has been extensively studied in a variety of human populations with both positive [45] and negative [46] results.

Another promising candidate from Bp168 is Solute Carrier family 4, anion exchanger, member 1 (SLC4A1). SLC4A1 is a polymorphism of one of our candidate genes and has been associated with both blood pressure variation and hypertension [47].

Bp186 is another overlapped QTL on this chromosome. It covers a region from $95,066,219 \mathrm{bp}$ to $110,718,848 \mathrm{bp}$ and contains 263 genes, which is roughly one gene per $59,515 \mathrm{bps}$. A total of five candidate genes were selected from these 263 genes, including ACE and Gh1, which are both overlapped by genes in Bp168.

Both NOS2 and ACE have been disqualified as QTLs in the Dahl salt-sensitive (DSS) and Lewis (LEW) rat comparison [48]. However, we did not find any report on the investigation of candidacy for either ALOX12, CIAS1, or SLC4A1 as the QTL for hypertension.

\subsubsection{Chromosome 11}

Chromosome 11 includes two QTL, Bp187 and BpQTLcluster 10. Bp187 is located in a $41,381,787$ bp region. It contains as many as 296 genes with an average of 139,803 bps per gene. However, it contains only two candidate genes, which means there is only one candidate gene per $20,690,893$ bps. No polymorphisms of these two genes, adp-ribosylation factor-like 6 and (AR16) superoxide dismutase 1 (SOD1), have been linked to human hypertension.

BpQTLcluster 10 covers a 45,000,000 bp region and has a total of 406 genes, with one gene per every 110,837 bps. It contains four candidate genes. This means there is a candidate gene from every 101 genes or every $11,250,000$ bps has one candidate gene. Among these four genes, SNP variations in calcium-sensing receptor (CASR) has been recently linked to human hypertension $[49,50]$. However, it has never been investigated as a candidate gene in this QTL. 


\subsubsection{Chromosome 15}

The three QTL found in Chromosome 15 are Bp191, Bp190, and Bp126. Bp191 is located on the proximal region covering a region of $14,323,976$ bps. It contains as many as 118 genes; however, none of them were selected as candidate genes by our bioinformatic searching. Since Bp190 is located within Bp126 they are considered the same QTL. Bp126 is found within a region of 2,000,000 bps on each side of the peak marker, Ednrb, and contains as many as 158 genes. However, similar to Bp191, there is no obvious candidate gene for hypertension from these 158 genes.

\subsection{Candidate Genes in Different QTL on the Same Chromosome Are Correlated to the Density of Genes in Each QTL Region}

In general, the number of candidate genes per QTL is directly correlated to the gene density in of the QTL region. The phenomenon is not restricted to the chromosomes in this study but holds true throughout every genome. The correlation between the total number of genes and the number of nucleotides in the QTL region is 0.817 (Figure 3(a)). The correlation between the total number of genes and the number of candidate genes in the QTL region is 0.827 (Figure 3(b)). QTL from several typical chromosomes are described as below.

\subsubsection{Chromosome 2}

Chromosome 2 includes the five QTL Bp115, Bp205, Bp14, Bp175, and Bp203. Bp115 is located on the proximal region covering a large $33,349,984 \mathrm{bp}$ region. It contains as many as 218 genes, with an average of 152,981 bps per gene. However, since it contains only five candidate genes there are an average of 669,966 bps per candidate gene. Of these five candidate genes, CAST, THBS4, and F2R are the most noteworthy.

Calpastatin (CAST) is among 16 genes that have shown linkage to human hypertension in the Japanese population. Wessel et al. [51] suggest that the A387P variant of the THBS4 gene may be an important determinant for the development of myocardial infarction at any age. Gigante B et al. [52] reported that F2R genetic

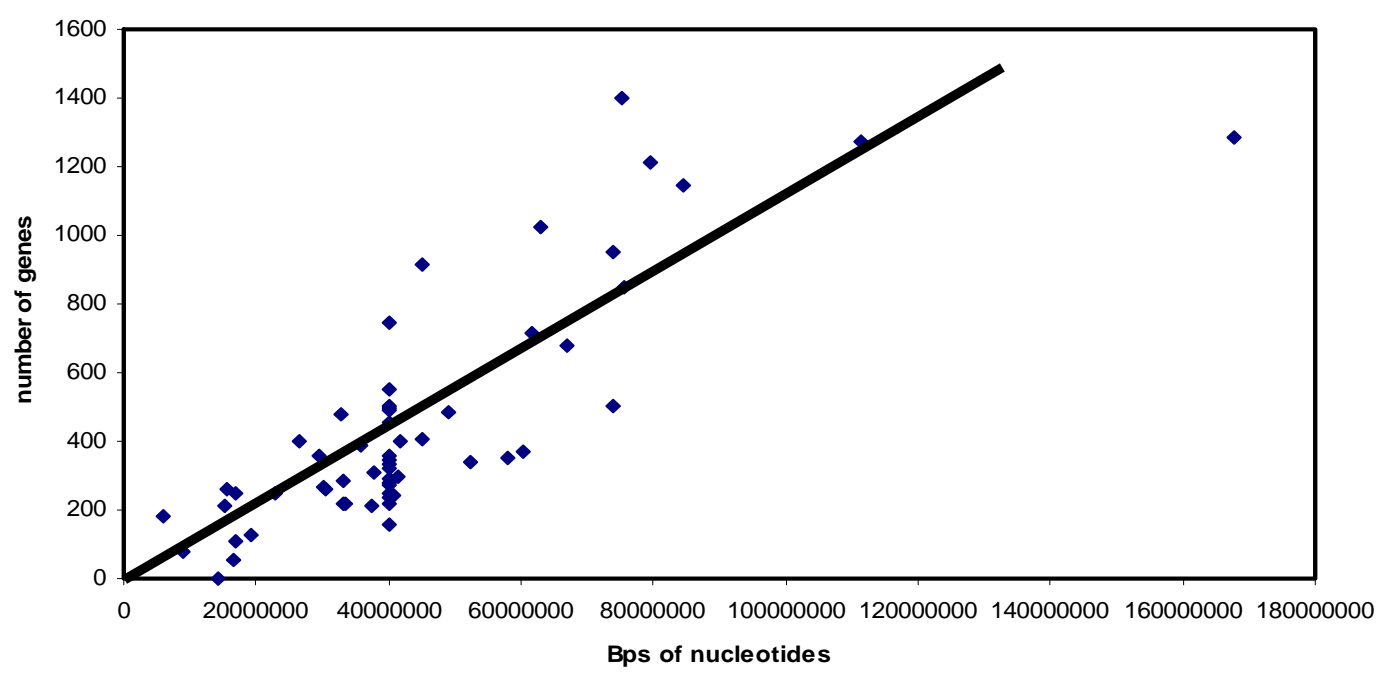

(a)

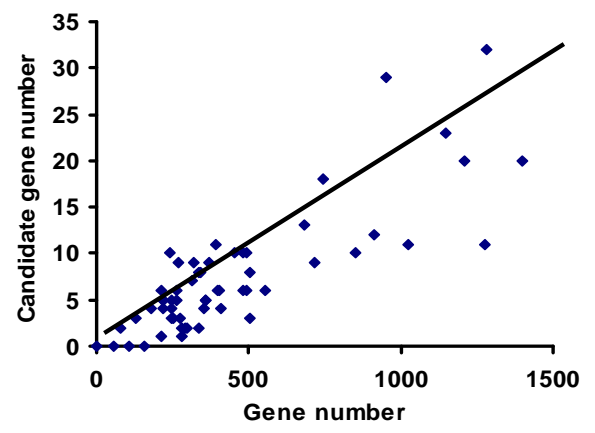

(b)

Figure 3. (a) Correlationship between number of base pairs of genome and number of genes in QTL regions; (b) Correlationship between number of genes and number of candidate genes for essential hypertension in QTL regions. 
variants may influence the natural history of coronary heart disease (CHD) in patients at high-risk for cardiovascular events.

Bp205 cover a 16,765,253 bp region and has on average one gene per 153,809 bps. However, it contains no candidate gene.

Bp14 is located next to Bp205. It covers $167,769,667$ bps and has a total of 1284 genes, with one gene per $130,661 \mathrm{bps}$. It contains 32 candidate genes or one candidate gene per 53 selected genes. On average, every $5,242,802$ bps has one candidate gene. Several important candidate genes include: NPR, GHR, CRH, GSTM, and ARNT. Allelic variants of natriuretic peptide receptor (NPR) genes are associated with a family history of hypertension and cardiovascular phenotypes [53], including Npr1 and Npr3. Another of the candidate genes, growth hormone receptor (GHR), has been linked to hypertension in two independent studies [19,54]. In "The Québec Family Study", a study of genome-wide linkage analysis for systolic and diastolic blood pressure, Rice et al. [55] found an association between polymorphisms of corticotrophin releasing hormone gene (CRH) and hypertension. A more recent study suggests that knowledge of glutathione s-transferase M1 (GSTM1) variant statuses is a potentially useful method for predicting a possible hypertensive status after 80 years of age in the Italian population [56]. Aryl hydrocarbon receptor nuclear translocator-like (ARNT) is associated with susceptibility to hypertension in a genetic association study designed to test the relevance of these findings in 1304 individuals from 424 families [57]. Glutathione s-transferase M3 (GSTM3) $-63 \mathrm{~A} / \mathrm{C}$ polymorphisms were associated with essential hypertension in Chinese Han populations. It is thought that the $\mathrm{C}$ allele might be a risk factor for $\mathrm{EH}$ in the Chinese Han ethnic group [58]. In a study by Delles et al., [59], it was found that a single nucleotide polymorphism in the 3' region of GSTM5 (rs11807) was associated with hypertension $(\mathrm{P}=0.01)$, and with the $\mathrm{T}$-allele being over-transmitted to hypertensive offspring.

The one exception that gene density is not associated with the number of candidate genes on chromosome 2 is the Bp203 QTL, which is overlapped with Bp14, that covers a $30,053,784$ bp region. It contains as many as 267 genes, which is an average of 112,560 bps per gene. It has nine candidate genes, which is one candidate gene per 3,339,309 bps. An interesting fact is that out of these nine candidate genes six of them are also found in Bp14.

Bp175 covers a $33,278,084$ bp region. It contains as many as 220 genes $(151,264$ bp per gene). It contains 4 candidate genes, which is one candidate gene per $8,319,521$ bps. However, none of these four genes have been linked to hypertension in humans.

\subsubsection{Chromosome 4}

Chromosome 4 includes the four QTL Bp179, Bp86,
Bp124, and Bp209, located proximal to distal, respecttively. Bp179 locates on the proximal region covers a $40,000,132$ bp region. It contains as many as 239 genes, with an average of 167,364 bps per gene. However, it contains only 10 candidate genes, which is an average of 4,000,013 bps per candidate gene. Key candidate genes from this QTL include HGF and LEP. Hepatocyte growth factor (HGF) is a growth factor that contributes to protection and/or repair of vascular endothelial cells. Two studies showed that C/A polymorphisms in intron 13 of the HGF gene are associated with susceptibility to essential hypertension in Japanese female subjects [60, 61]. Leptin (LEP) has been widely investigated for its role in hypertension. A recent study indicates that common LEP polymorphisms are associated with blood pressure in the Brazilian Tunisian population [62].

Bp86 has a little overlap with Bp179 and covers a $35,960,924 \mathrm{bp}$ region. It contains total of 1284 genes, with one gene per 92,207 bps. It has 11 candidate genes, or one candidate gene per 35 selected genes. On average, every 3,269,174 bp has at least one candidate gene. The most probable candidate gene from Bp86 is Lep, which is overlapped from Bp179, since none of other genes are linked to human hypertension.

Bp124 is largely overlapped with Bp 86 and covers a $40,000,190 \mathrm{bp}$ region. It contains as many as 456 genes, and has an average of 87,719 bps per gene. It has 10 candidate genes, which is one candidate gene per 4,000,019 bps. Eight of these 10 candidate genes are overlapped with Bp86. The other two genes have no known association with hypertension.

Bp209 covers a 40,000,115 bp region. It contains as many as 251 genes, with an average of 159,363 bps per gene. It has only three candidate genes, or one candidate gene per 13,333,371 bps. Among those three genes, only the CC genotype in oxidized LDL receptor gene (OLR-1) is an independent risk factor for hypertension in the Chinese population [63].

\subsubsection{Chromosome 8}

On chromosome 8 the three QTL, are Bp184, Bp262, and Bp263. Bp262 is located in a 75,560,673 bp region close to proximal end. It has one gene per 88,999 bps and one candidate gene from every 85 genes. One average, there is one candidate gene per 7,556,067 bps. Three of the ten selected candidate genes showed association with human hypertension. Recently, it was reported that five polymorphisms in the KCNJ1 gene coding for the potassium channel, ROMK, showed associations with mean 24-hour systolic or diastolic blood pressure [25,46]. Another candidate gene, Cytochrome P450, family 1, subfamily A, polypeptide 1 (CYP1A1) has been studied in several populations, and, particularly, the $\mathrm{T} 6325 \mathrm{C}$ polymorphism is thought to modulate essential hyperten- 
sion-associated stroke risk [64].

Bp 184 is partially overlapped with Bp262 and has one gene per 101,726 bps with one candidate gene per 80 genes. One average, there is one candidate gene per $8,188,965$ bps.

Bp 263 has one gene per 82,646 bps. Six genes were selected as candidate genes, with one candidate gene per 71 genes. One average, one candidate gene is found per $5,900,984$ bps. Only one candidate gene is associated with hypertension in human populations. In a study of the $206 \mathrm{M}$ polymorphic variant of the SLC26A6 gene encoding a $\mathrm{Cl}(-)$-oxalate transporter in patients with primary hyperparathyroidism, Corbetta et al. [65] found that the SLC26A6 206M alleles were significantly related to the presence of hypertension.

Bp263 is essentially the same as Bp184 and SLC26A6 is also included as a candidate gene for this locus.

\subsubsection{Chromosome 9}

Chromosome 9 includes the two QTL Bp34 and Bp185. $\mathrm{Bp} 34$ is located on a region covering $37,780,765$ bps. It contains as many as 311 genes, with an average of 121,482 bps per gene. However, there is an average of $5,397,252$ bps per candidate gene. Of the candidate genes, Cytotoxic T-lymphocyte-associated protein 4 (CTLA4) is among the polymorphisms from 16 genes that are significantly associated with blood pressure variations (29) in the Japanese population.

Bp185 cover a 40,000,158 bp region and has a total of 343 genes, with 116,618 bps per gene. It also has one candidate gene per 43 genes. On average, every $6,666,669$ bps contains one candidate gene. Wen et al. [66] reported evidence for the association between a regulatory polymorphism in Secretogranin II (SCG2) and hypertension in African-American subjects.

\subsubsection{Chromosome 14}

Chromosome 14 includes the two QTL Bp189 and Bp59. Bp189 is located on a region covering 40,799,268 bps. It contains as many as 245 genes, with an average of 166,527 bps per gene. However, it only contains three candidate genes, which is an average of 13,599,756 bps per candidate gene. Dries et al. [67] showed that the Corin gene minor allele defined by 2 missense mutations is common in African-Americans and is associated with high blood pressure and hypertension. Their study was also confirmed in later study comprising the Chinese population [68]. Another of the candidate genes is extracellular superoxide dismutase gene (SOD3). Based on the results from Naganuma et al. [69] who utilized a haplotype-based case-control study, a T-A haplotype of the SOD gene may be a genetic marker for essential hypertension.

Bp59 covers a $15,236,276$ bp region and has a total of
214 genes, with 71,197 bps per gene. It has one candidate gene per 36 selected gene. On average, every 2,539,379 bps contains one candidate gene. Adducin (ADD1) is a candidate gene for salt-sensitive hypertension. The association between ADD1 and essential hypertension has been well documented [70,71]. G protein-coupled receptor kinases (GRKs) polymorphisms that lead to aberrant action of GRKs cause a number of conditions, which include hypertension and salt sensitive- ity. Polymorphisms in one particular member of this family, GRK4, have been shown to cause hyperphosphorylation, desensitization, and internalization [72]. Yamada et al. suggested that the genotypes for ITGA2, GCK, and PTGIS may prove reliable for the assessment of the genetic component of hypertension. There claim was based on their study of a population comprised of 4853 unrelated Japanese individuals, including 2818 subjects with hypertension [73].

\subsubsection{Chromosome 18}

Chromosome 18 includes the three QTL Bp2, Bp233, and Bp48.

$\mathrm{Bp} 2$ is located on the proximal region of the chromosome and consists of $33,239,845 \mathrm{bps}$. It contains as many as 282 genes, and has on average 117,871 bps per gene. However, there is an average of $16,619,922$ bps per candidate gene. There are only two candidate genes in this QTL, and only one (ROCK) with any linkage to EH in the human population. A Rho kinase (ROCK) polymerphism influences blood pressure and systemic vascular resistance in human twins [74].

Bp233 covers a 40,000,179 bp region and has a total of 319 genes, with 125,392 bps per gene. It has one candidate gene per 40 selected genes. On average, every $5,000,022$ bps contains one candidate gene.

Bp48 covers a 19,324,774 bp region and has a total of 128 genes, with 150,974 bps per gene. There is one candidate gene per 43 selected genes. On average, every $6,441,591$ bps contains one candidate gene.

\subsection{Candidate Genes in the Peak Region of the QTL Compared to Candidate Genes in the QTL Region}

As indicated in our method, we selected QTL with LOD scores that are $\geq 2$.8. However, QTL usually produce a curved or bell-shaped region. Thus, the LOD score at the top of the bell, the peak point, has the highest value. Theoretically, the higher a LOD score is the higher the probability there is a QTL. We then ask the question, if the LOD score in the peak region is high is the probability of a QTL gene in or near the peak point also high? Therefore, based on our assumptions we examined the number of candidate genes within $1.5 \mathrm{mbps}$ on each side 
of the peak region.

As expected, there was a much high probability of candidate genes in those $1.5 \mathrm{mbp}$ regions. In the whole rat genome, we obtained one candidate gene from every $12,594,138$ bps. Of all the QTL, we have information on the peak positions of 45 QTL. From these 45 peak regions, we obtained 21 candidate genes (Table 1). On average, there are one candidate gene per $7.105 \mathrm{mbps}$ in the peak region of a QTL. However, these 21 candidate genes are from only 13 QTL peak regions. The peak regions for the rest of 26 QTL do not contain obvious candidate genes (Supplementary Table 1).

Among these 13 peak regions, one region has three candidate genes while in each of other four regions there are 2 candidate genes (Table 1). There is no correlation between the number of candidate genes in a peak region and the number of total genes in a QTL region $(\mathrm{R}=$ $-0.084)$. However, there is a weak negative correlation between the bps per candidate gene and the number of candidate genes in a peak region $(\mathrm{R}=-0.325)$. Overall, the number of candidate genes in a peak region appears independent from other factors in this study.

Among all the QTL we examined, only Bp124 on chromosome 4 contained three candidate genes in its peak region. This QTL is located on a gene rich region with a LOD score of 3. It also contains a total of 456 genes with an average of 87,719 bps per gene. The three candidate genes from this QTL are from a pool of 10 candidates. The three candidates are Phosphodiesterase 1c (PDE1c), Aquaporin 1 (AQP1) and CorticotropinReleasing Hormone Receptor 2 (CRHR2). Recent reports indicate that members in the calcium/calmodulindependent phosphodiesterase 1 (PDE1) family may play a major role in vascular smooth muscle cell proliferation. Particularly, PDE1c has been known to contribute to decreased cAMP production and increased proliferation of pulmonary areterial smooth muscle cells (PASMC) in patients with pulmonary hypertension (PHT) [75]. AQP1 is abundant in renal proximal tubular epithelium, the thin descending limb of the loop of Henle, and the descending vasa recta of the kidney. In 2006, Lee et al. [76] reported that the expression of AQP1-3 channels is increased in the kidney in association with enhanced activity of the AVP/cAMP pathway in spontaneously hypertensive rats.

CRHR2 is known for its important role in coordinating the endocrine, autonomic, and behavioral responses to stress and immune challenges [77]. In a study of an Antalarmin blockade of corticotropin releasing hormoneinduced hypertension in rats, Briscoe and colleagues [78] reported that the hypertension produced by central CRH administration is mediated through central CRHR1 receptors, whereas, the hypertension produced by parenteral CRH administration is mediated through periph- eral CRHR2 receptors. It would be very interesting to know whether all, or any of these three genes, are the causal genes for hypertension's QTL.

\section{CONCLUSIONS}

Our investigation raises an important issue in the selection of candidate genes for specific QTLs, the consideration of the position of a gene in the QTL region. Our data suggests that a gene in the peak region of a QTL is of more relative importance than a gene further from the peak position. Theoretically, this agrees with the definition of the LOD score. From experience, many QTL genes have been identified from positions that are close to the peak region of the QTL.

The other issue our investigation discovered is whether candidate genes can be easily identified from a QTL located in either gene-rich or gene-poor regions. In our study, we found that QTL located in both gene-rich regions and gene-rich chromosomes contained the most candidate genes. However, the number of candidate genes within a peak region is not associated with the number of total genes in a QTL region. Also, more candidate genes does not necessary indicate that the real, causal gene is among these genes. Similarly, less candidate genes in the QTL of gene-poor regions or gene-poor chromosomes does not necessary mean that the analysis is easy due to the smaller number of candidate genes.

The fact from our study is that there are an extremely large number of genome regions and genes covered by the hypertension QTLs. Even though our search for candidate genes was limited to just essential hypertension, we still obtained 266 candidate genes. Considering the large number of QTL and genetic and environmental factors, identification of the QTL for hypertension without defined environmental conditions and a unified genomic background is extremely difficult.

\section{ACKNOWLEDGEMENTS}

Support for this work is from Center of Genomics and Bioinformatics (WG) and Center in Connective Tissue Research (WG), at University of Tennessee Health Science Center; Veterans Administration (WG); National Institute on Alcohol Abuse and Alcoholism (NIAAA), National Institutes of Health (1R01AA016342 to WG) and the Center of Integrating Genomics and Bioinformatics for International Studying of Strokes, the University of Tennessee Health Science Center, and the Veterans Administration Medical Center, Memphis, TN. Funding for YJW is from the "Major Project of Chinese National Programs for Fundamental Research and Development (No.2009CB521905).”

\section{REFERENCES}

[1] Chauvet, C., Ménard, A., Xiao, C., Aguila, B., Blain, M., Roy, J. and Deng, A.Y. (2012) Novel genes as primary 
triggers for polygenic hypertension. Journal of Hypertension, 30, 81-86. doi:10.1097/HJH.0b013e32834dddb1

[2] Simino, J., Shi, G., Kume, R., Schwander, K., Province, M.A., Gu, C.C., Kardia, S., Chakravarti, A., Ehret, G., Olshen, R.A., Turner, S.T., Ho, L.T., Zhu, X., Jaquish, C., Paltoo, D., Cooper, R.S., Weder, A., Curb, J.D., Boerwinkle, E., Hunt, S.C. and Rao, D.C. (2011) Five blood pressure loci identified by an updated genome-wide linkage scan: Meta-analysis of the Family Blood Pressure Program. American Journal of Hypertension, 24, 347354. doi:10.1038/ajh.2010.238

[3] Johnson, M.D., He, L., Herman, D., Wakimoto, H., Wallace, C.A., Zidek, V., Mlejnek, P., Musilova, A., Simakova, M., Vorlicek, J., Kren, V., Viklicky, O., Qi, N.R., Wang, J., Seidman, C.E., Seidman, J., Kurtz, T.W., Aitman, T.J. and Pravenec, M. (2009) Dissection of chromosome 18 blood pressure and salt-sensitivity quantitative trait loci in the spontaneously hypertensive rat. Hypertension, 54, 639-645.

doi:10.1161/HYPERTENSIONAHA.108.126664

[4] Deng, A.Y. (2007) Genetic basis of polygenic hypertension. Human Molecular Genetics, 16, R195-R202. doi: $10.1093 / \mathrm{hmg} / \mathrm{ddm} 126$

[5] Cowley Jr., A.W. (2006) The genetic dissection of essential hypertension. Nature Reviews Genetics, 7, 829-840. doi:10.1038/nrg1967

[6] Twigger, S.N., Shimoyama, M., Bromberg, S., Kwitek, A.E., Jacob, H.J. and RGD Team (2007) The Rat Genome Database, update 2007-Easing the path from disease to data and back again. Nucleic Acids Research, 35, D658-D662. doi:10.1093/nar/gk1988

[7] Tobin, M.D., Tomaszewski, M., Braund, P.S., Hajat, C., Raleigh, S.M., Palmer, T.M., Caulfield, M., Burton, P.R. and Samani, N.J. (2008) Common variants in genes underlying monogenic hypertension and hypotension and blood pressure in the general population. Hypertension, 51, 1658-1664. doi:10.1161/HYPERTENSIONAHA.108.112664

[8] Thomas, G.N., Critchley, J.A., Tomlinson, B., Cockram, C.S. and Chan, J.C. (2001) Relationships between the taqI polymorphism of the dopamine D2 receptor and blood pressure in hyperglycaemic and normoglycaemic Chinese subjects. Clinical Endocrinology, 55, 605-611.

[9] Xiong, Q., Qiu, Y. and Gu, W. (2008) PGMapper: A web-based tool linking phenotype to genes. Bioinformatics, 24, 1011-1013. doi:10.1093/bioinformatics/btn002

[10] Lander, E. and Kruglyak, L. (1995) Genetic dissection of complex traits: Guidelines for interpreting and reporting linkage results. Nature Genetics, 11, 241-247. doi:10.1038/ng1195-241

[11] Van Ooijen, J.W. (1992) Accuracy of mapping quantitative trait loci in autogamous species. TAG Theoretical and Applied Genetics, 84, 9.

[12] Yasui, N., Kajimoto, K., Sumiya, T., Okuda, T. and Iwai, N. (2007) The monocyte chemotactic protein-1 gene may contribute to hypertension in Dahl salt-sensitive rats. Hypertension Research, 30, 185-193. doi:10.1291/hypres.30.185
[13] Denag, A.Y. (1998) Is the nitric oxide system involved in genetic hypertension in Dahl rats? Kidney International, 53, 1501-1511. doi:10.1046/j.1523-1755.1998.00933.x

[14] Ye, P. and West, M.J. (2003) Cosegregation analysis of natriuretic peptide genes and blood pressure in the spontaneously hypertensive rat. Clinical and Experimental Pharmacology and Physiology, 30, 930-936. doi:10.1111/j.1440-1681.2003.03937.x

[15] Suthanthiran, M., Li, B., Song, J.O., Ding, R., Sharma, V.K., Schwartz, J.E. and August, P. (2000) Transforming growth factor-beta-1 hyperexpression in African-American hypertensives: A novel mediator of hypertension and/or target organ damage. Proceedings of the National Academy of Sciences, 97, 3479-3484.

[16] Petretto, E., Sarwar, R., Grieve, I., Lu, H., Kumaran, M.K., Muckett, P.J., Mangion, J., Schroen, B., Benson, M., Punjabi, P.P., Prasad, S.K., Pennell, D.J., Kiesewetter, C., Tasheva, E.S., Corpuz, L.M., Webb, M.D., Conrad, G.W., Kurtz, T.W., Kren, V., Fischer, J., Hubner, N., Pinto, Y.M., Pravenec, M., Aitman, T.J. and Cook, S.A. (2008) Integrated genomic approaches implicate osteoglycin (Ogn) in the regulation of left ventricular mass. Nature Genetics, 40, 546-552. doi:10.1038/ng.134

[17] Frikke-Schmidt, R., Sing, C.F., Nordestgaard, B.G., Steffensen, R. and Tybjaerg-Hansen, A. (2007) Subsets of SNPs define rare genotype classes that predict ischemic heart disease. Human Genetics, 120, 865-877. doi:10.1007/s00439-006-0233-y

[18] Koo, B.K., Cho, Y.M., Park, B.L., Cheong, H.S., Shin, H.D., Jang, H.C., Kim, S.Y., Lee, H.K. and Park, K.S. (2007) Polymorphisms of KCNJ11 (Kir6.2 gene) are associated with Type 2 diabetes and hypertension in the Korean population. Diabetic Medicine, 24, 178-186. doi:10.1111/j.1464-5491.2006.02050.x

[19] Kokubo, Y., Tomoike, H., Tanaka, C., Banno, M., Okuda, T., Inamoto, N., Kamide, K., Kawano, Y. and Miyata, T. (2006) Association of sixty-one non-synonymous polymerphisms in forty-one hypertension candidate genes with blood pressure variation and hypertension. Hypertension Research, 29, 611-619. doi:10.1291/hypres.29.611

[20] Iwai, N., Tago, N., Yasui, N., Kokubo, Y., Inamoto, N., Tomoike, H. and Shioji, K. (2004) Genetic analysis of 22 candidate genes for hypertension in the Japanese population. Journal of Hypertension, 22, 1119-1126. doi:10.1097/00004872-200406000-00012

[21] Busjahn, A., Aydin, A., Uhlmann, R., Krasko, C., Bähring, S., Szelestei, T., Feng, Y., Dahm, S., Sharma, A.M., Luft, F.C. and Lang, F. (2002) Serum- and glucocorticoid-regulated kinase (SGK1) gene and blood pressure. Hypertension, 40, 256-260. doi:10.1161/01.HYP.0000030153.19366.26

[22] Trochen, N., Ganapathipillai, S., Ferrari, P., Frey, B.M. and Frey, F.J. (2004) Low prevalence of nonconservative mutations of serum and glucocorticoid-regulated kinase (SGK1) gene in hypertensive and renal patients. Nephrology Dialysis Transplantation, 19, 2499-2504. doi:10.1093/ndt/gfh417

[23] Lazar, A., Zimmermann, T., Koch, W., Gründemann, D., 
Schömig, A., Kastrati, A. and Schömig, E. (2006) Lower prevalence of the OCT2 Ser270 allele in patients with essential hypertension. Clinical and Experimental Hypertension, 28, 645-653. doi:10.1080/10641960600946411

[24] Wang, L., Feng, Y., Zhang, Y., Zhou, H., Jiang, S., Niu, T., Wei, L.J., Xu, X., Xu, X. and Wang, X. (2006) Prolylcarboxypeptidase gene, chronic hypertension, and risk of preeclampsia. American Journal of Obstetrics \& Gynecology, 195, 162-171.

doi:10.1016/j.ajog.2006.01.079

[25] Tobin, M.D., Tomaszewski, M., Braund PS, Hajat C, Raleigh SM, Palmer TM, Caulfield, M., Burton, P.R. and Samani, N.J. (2008) Common variants in genes underlying monogenic hypertension and hypotension and blood pressure in the general population. Hypertension, 51, 1658-1664.

doi:10.1161/HYPERTENSIONAHA.108.112664

[26] Büsst, C.J., Scurrah, K.J., Ellis, J.A. and Harrap, S.B. (2007) Selective genotyping reveals association between the epithelial sodium channel gamma-subunit and systolic blood pressure. Hypertension, 50, 672-678. doi:10.1161/HYPERTENSIONAHA.107.089128

[27] Iwai, N., Baba, S., Mannami, T., Katsuya, T., Higaki, J., Ogihara, T. and Ogata, J. (2001) Association of sodium channel gamma-subunit promoter variant with blood pressure. Hypertension, 38, 86-89. doi:10.1161/01.HYP.38.1.86

[28] Sáez, M.E., Martínez-Larrad, M.T., Ramírez-Lorca, R., González-Sánchez, J.L., Zabena, C., Martinez-Calatrava, M.J., González, A., Morón, F.J., Ruiz, A. and SerranoRíos, M. (2007) Calpain-5 gene variants are associated with diastolic blood pressure and cholesterol levels. BMC Medical Genetics, 8, 1.

[29] Iwai, N., Kajimoto, K., Kokubo, Y. and Tomoike, H. (2006) Extensive genetic analysis of 10 candidate genes for hypertension in Japanese. Hypertension, 48, 901-907. doi:10.1161/01.HYP.0000242485.23148.bb

[30] Ji, Q., Ikegami, H., Fujisawa, T., Kawabata, Y., Ono, M., Nishino, M., Ohishi, M., Katsuya, T., Rakugi, H. and Ogihara, T. (2004) A common polymorphism of uncoupling protein 2 gene is associated with hypertension. Journal of Hypertension, 22, 97-102. doi:10.1097/00004872-200401000-00018

[31] Matsunaga, T., Gu, N., Yamazaki, H., Tsuda, M., Adachi, T., Yasuda, K., Moritani, T., Tsuda, K., Nonaka, M. and Nishiyama, T. (2009) Association of UCP2 and UCP3 polymorphisms with heart rate variability in Japanese men. Journal of Hypertension, 27, 305-313. doi:10.1097/HJH.0b013e32831ac967

[32] Marçano, A.C., Burke, B., Gungadoo, J., Wallace, C., Kaisaki, P.J., Woon, P.Y., Farrall, M., Clayton, D., Brown, M., Dominiczak, A., Connell, J.M., Webster, J., Lathrop, M., Caulfield, M., Samani, N., Gauguier, D., Munroe, P.B. (2007) Genetic association analysis of inositol polyphosphate phosphatase-like 1 (INPPL1, SHIP2) variants with essential hypertension. Journal of Medical Genetics, 44, 603-605. doi:10.1136/jmg.2007.049718
[33] Gaukrodger, N., Avery, P.J. and Keavney, B. (2008) Plasma potassium level is associated with common genetic variation in the beta-subunit of the epithelial sodium channel. American Journal of Physiology-Regulatory, Integrative and Comparative Physiology, 294, R1068R1072. doi:10.1152/ajpregu.00732.2007

[34] Jin, Y., Kuznetsova, T., Tikhonoff, V., Thijs, L., Hasenkamp, S., Bäumer, V., Stolarz-Skrzypek, K., Ryabikov, A., Richart, T., Malyutina, S., Nikitin, Y., Casiglia, E., Kawecka-Jaszcz, K., Olszanecka, A., Brand-Herrmann, S.M., Brand, E., Fagard, R., Staessen, J.A. and European Project on Genes in Hypertension (EPOGH) Investigators (2009) Left ventricular structure in relation to the human SAH gene in the European Project on Genes in Hypertension. Hypertension Research, 32, 145-151. doi: $10.1038 / \mathrm{hr} .2008 .30$

[35] Tikhonoff, V., Staessen, J.A., Kuznetsova, T., Thijs, L., Hasenkamp, S., Bäumer, V., Stolarz, K., Seidlerová, J., Filipovský, J., Nikitin, Y., Peleska, J., Kawecka-Jaszcz, K., Casiglia, E., Brand-Herrmann, S.M., Brand, E. and European Project on Genes in Hypertension (EPOGH) Investigators (2008) SAH gene variants revisited in the European Project On Genes in Hypertension. Journal of Hypertension, 26, 244-250. doi:10.1097/HJH.0b013e3282f2d36f

[36] Yuan, Z., Su, Z., Miyoshi, T., Rowlan, J.S. and Shi, W. (2008) Quantitative trait locus analysis of circulating adhesion molecules in hyperlipidemic apolipoprotein E-deficient mice. Molecular Genetics and Genomics, 280, 375-383. doi:10.1007/s00438-008-0371-0

[37] Okuda, T., Sumiya, T., Mizutani, K., Tago, N., Miyata, T., Tanabe, T., Kato, H., Katsuya, T., Higaki, J., Ogihara, T., Tsujita, Y. and Iwai, N. (2002) Analyses of differential gene expression in genetic hypertensive rats by microarray. Hypertension Research, 25, 249-255. doi:10.1291/hypres.25.249

[38] Tripodi, G., Modica, R., Stella, A., Bigatti, G., Bianchi, G. and Stella, P. (2005) Haplotype analysis of carnitine transporters and left ventricular mass in human essential hypertension. Journal of Renal Nutrition, 15, 2-7. doi:10.1053/i.jrn.2004.09.035

[39] Kohara, K., Tabara, Y., Nakura, J., Imai, Y., Ohkubo, T., Hata, A., Soma, M., Nakayama, T., Umemura, S., Hirawa, N., Ueshima, H., Kita, Y., Ogihara, T., Katsuya, T., Takahashi, N., Tokunaga, K. and Miki, T. (2008) Identification of hypertension-susceptibility genes and pathways by a systemic multiple candidate gene approach: The millennium genome project for hypertension. Hypertension Research, 31, 203-212. doi:10.1291/hypres.31.203

[40] Kawaguchi, Y., Tochimoto, A., Hara, M., Kawamoto, M., Sugiura, T., Katsumata, Y., Okada, J., Kondo, H., Okubo, M. and Kamatani, N. (2006) $\mathrm{NOS}_{2}$ polymorphisms associated with the susceptibility to pulmonary arterial hypertension with systemic sclerosis: Contribution to the transcriptional activity. Arthritis Research \& Therapy, 8, R104. doi:10.1186/ar1984

[41] Jemaa, R., Ben, A.S., Kallel, A., Omar, S., Feki, M., Elasmi, M., Haj-Taïeb, S., Sanhaji, H. and Kaabachi, N. (2009) Association between the -2518G/A polymorphism in the monocyte chemoattractant protein-1 (MCP-1) gene 
and hypertension in Tunisian patients. Clinical Biochemistry, 42, 34-37. doi:10.1016/j.clinbiochem.2008.09.118

[42] Quintana, L.F., Guzmán, B., Collado, S., Clària, J. and Poch, E. (2006) A coding polymorphism in the 12-lipoxygenase gene is associated to essential hypertension and urinary 12(S)-HETE. Kidney International, 69, 526-530. doi:10.1038/sj.ki.5000147

[43] Omi, T., Kumada, M., Kamesaki, T., Okuda, H., Munkhtulga, L., Yanagisawa, Y., Utsumi, N., Gotoh, T., Hata, A., Soma, M., Umemura, S., Ogihara, T., Takahashi, N., Tabara, Y., Shimada, K., Mano, H., Kajii, E., Miki, T. and Iwamoto, S. (2006) An intronic variable number of tandem repeat polymorphisms of the cold-induced autoinflammatory syndrome 1 (CIAS1) gene modifies gene expression and is associated with essential hypertension. European Journal of Human Genetics, 14, 1295-1305. doi:10.1038/sj.ejhg. 5201698

[44] Timasheva, Y.R., Nasibullin, T.R., Zakirova, A.N. and Mustafina, O.E. (2008) Association of interleukin-6, interleukin-12, and interleukin-10 gene polymorphisms with essential hypertension in Tatars from Russia. Biochemical Genetics, 46, 64-74. doi:10.1007/s10528-007-9130-x

[45] Sink, K.M., Leng, X., Williamson, J., Kritchevsky, S.B., Yaffe, K., Kuller, L., Yasar, S., Atkinson, H., Robbins, M., Psaty, B. and Goff Jr., D.C. (2009) Angiotensinconverting enzyme inhibitors and cognitive decline in older adults with hypertension: Results from the Cardiovascular Health Study. Archives of Internal Medicine, 169, 1195-1202.

doi:10.1001/archinternmed.2009.175

[46] Woo, S.W., Bang, S., Chung, M.W., Jin, S.K., Kim, Y.S. and Lee, S.H. (2009) Lack of association between ACE and bradykinin B2 receptor gene polymorphisms and ACE inhibitor-induced coughing in hypertensive Koreans. Journal of Clinical Pharmacy and Therapeutics, 34, 561-567. doi:10.1111/j.1365-2710.2009.01028.x

[47] Kokubo, Y., Tomoike, H., Tanaka, C., Banno, M., Okuda, T., Inamoto, N., Kamide, K., Kawano, Y. and Miyata, T. (2006) Association of sixty-one non-synonymous polymorphisms in forty-one hypertension candidate genes with blood pressure variation and hypertension. Hypertension Research, 29, 611-619. doi:10.1291/hypres.29.611

[48] Palijan, A., Lambert, R., Dutil, J., Sivo, Z. and Deng, A.Y. (2003) Comprehensive congenic coverage revealing multiple blood pressure quantitative trait loci on Dahl rat chromosome 10. Hypertension, 42, 515-522. doi:10.1161/01.HYP.0000090096.88509.15

[49] Jung, J., Foroud, T.M., Eckert, G.J., Flury-Wetherill, L., Edenberg, H.J., Xuei, X., Zaidi, S.A. and Pratt, J.H. (2009) Association of the calcium-sensing receptor gene with blood pressure and urinary calcium in AfricanAmericans. Journal of Clinical Endocrinology \& $\mathrm{Me}$ tabolism, 94, 1042-1048. doi:10.1210/jc.2008-1861

[50] Tobin, M.D., Tomaszewski, M., Braund, P.S., Hajat, C., Raleigh, S.M., Palmer, T.M., Caulfield, M., Burton, P.R. and Samani, N.J. (2008) Common variants in genes underlying monogenic hypertension and hypotension and blood pressure in the general population. Hypertension, 51, 1658-1664. doi:10.1161/HYPERTENSIONAHA.108.112664

[51] Wessel, J., Topol, E.J., Ji, M., Meyer, J. and McCarthy, J.J. (2004) Replication of the association between the thrombospondin-4 A387P polymorphism and myocardial infarction. American Heart Journal, 147, 905-909. doi:10.1016/j.ahj.2003.12.013

[52] Gigante, B., Bellis, A., Visconti, R., Marino, M., Morisco, C., Trimarco, V., Galasso, G., Piscione, F., De Luca, N., Prince, J.A., de Faire, U. and Trimarco, B. (2007) Retrospective analysis of coagulation factor II receptor (F2R) sequence variation and coronary heart disease in hypertensive patients. Arteriosclerosis, Thrombosis, and Vascular Biology, 27, 1213-1219. doi:10.1161/ATVBAHA.107.140541

[53] Pitzalis, M.V., Sarzani, R., Dessì-Fulgheri, P., Iacoviello, M., Forleo, C., Lucarelli, K., Pietrucci, F., Salvi, F., Sorrentino, S., Romito, R., Guida, P., Rappelli, A. and Rizzon, P. (2003) Allelic variants of natriuretic peptide receptor genes are associated with family history of hypertension and cardiovascular phenotype. Journal of Hypertension, 21, 1491-1496.

doi:10.1097/00004872-200308000-00012

[54] Horan, M., Newsway, V., Yasmin, Lewis, M.D., Easter, T.E., Rees, D.A., Mahto, A., Millar, D.S., Procter, A.M., Scanlon, M.F., Wilkinson, I.B., Hall, I.P., Wheatley, A., Blakey, J., Bath, P.M., Cockcroft, J.R., Krawczak, M. and Cooper, D.N. (2006) Genetic variation at the growth hormone (GH1) and growth hormone receptor (GHR) loci as a risk factor for hypertension and stroke. Human Genetics, 119, 527-540. doi:10.1007/s00439-006-0166-5

[55] Rice, T., Rankinen, T., Province, M.A., Chagnon, Y.C., Pérusse, L., Borecki, I.B., Bouchard, C. and Rao, D.C. (2000) Genome-wide linkage analysis of systolic and diastolic blood pressure: The Québec Family Study. Circulation, 102, 1956-1963.

doi:10.1161/01.CIR.102.16.1956

[56] Capoluongo, E., Onder, G., Concolino, P., Russo, A., Santonocito, C., Bernabei, R., Zuppi, C., Ameglio, F. and Landi, F. (2009) GSTM1-null polymorphism as possible risk marker for hypertension: results from the aging and longevity study in the Sirente Geographic Area (ilSIRENTE study). Clinica Chimica Acta, 399, 92-96. doi:10.1016/j.cca.2008.09.017

[57] Woon, P.Y., Kaisaki, P.J., Bragança, J., Bihoreau, M.T., Levy, J.C., Farrall, M. and Gauguier, D. (2007) Aryl hydrocarbon receptor nuclear translocator-like (BMAL1) is associated with susceptibility to hypertension and type 2 diabetes. Proceedings of the National Academy of Sciences, 104, 14412-14417. doi:10.1073/pnas.0703247104

[58] Liu, J., Li, M., Qi, M.L., Liu, X.L., Li, Y.H., Fu, L.Y. and Zhao, Y.Y. (2007) Association of $-63 \mathrm{~A} / \mathrm{C}$ polymorphism of glutathione S-transferase M3 gene with essential hypertension in Chinese population. Chinese Journal of Medical Genetics, 24, 582-585.

[59] Delles, C., Padmanabhan, S., Lee, W.K., Miller, W.H., 
McBride, M.W., McClure, J.D., Brain, N.J., Wallace, C., Marçano, A.C., Schmieder, R.E., Brown, M.J., Caulfield, M.J., Munroe, P.B., Farrall, M., Webster, J., Connell, J.M. and Dominiczak, A.F. (2008) Glutathione S-transferase variants and hypertension. Journal of Hypertension, 26, 1343-1352. doi:10.1097/HJH.0b013e3282fe1d67

[60] Motone, M., Katsuya, T., Ishikawa, K., Iwashima, Y., Sugimoto, K., Yamamoto, K., Fu, Y., Matsuo, A., Ohishi, M., Rakugi, H. and Ogihara, T. (2004) Association between hepatocyte growth factor gene polymorphism and essential hypertension. Hypertension Research, 27, 247251. doi:10.1291/hypres.27.247

[61] Takiuchi, S., Mannami, T., Miyata, T., Kamide, K., Tanaka, C., Kokubo, Y., Koyama, Y., Inamoto, N., Katsuya, T., Iwai, N., Kawano, Y., Ogihara, T. and Tomoike, H. (2004) Identification of 21 single nucleotide polymerphisms in human hepatocyte growth factor gene and association with blood pressure and carotid atherosclerosis in the Japanese population. Atherosclerosis, 173, 301-307. doi:10.1016/j.atherosclerosis.2003.12.020

[62] Genelhu, V.A., Celoria, B.M., Pimentel, M.M., Duarte, S.F., Cabello, P.H. and Francischetti, E.A. (2009) Association of a common variant of the leptin gene with blood pressure in an obese Brazilian population. American Journal of Hypertension, 22, 577-580. doi:10.1038/ajh.2009.7

[63] Hou, X.W., Wang, L.F., Wang, N., Pang, D., Hui, B., Zhou, Y.L. and He, X. (2008) The G501C polymorphism of oxidized LDL receptor gene [OLR-1] is associated with susceptibility and serum C-reactive protein concentration in Chinese essential hypertensives. Clinica Chimica Acta, 388, 200-203. doi:10.1016/i.cca.2007.11.016

[64] Lança, V., Alcântara, P., Braz-Nogueira, J. and Bicho, M.P. (2004) Cytochrome P450 1A1 (CYP1A1) T6325C polymorphism might modulate essential hypertensionassociated stroke risk. Revista Portuguesa de Cardiologia, 23, 343-355.

[65] Corbetta, S., Eller-Vainicher, C., Frigerio, M., Valaperta, R., Costa, E., Vicentini, L., Baccarelli, A., Beck-Peccoz, P. and Spada, A. (2009) Analysis of the 206 M polymerphic variant of the SLC26A6 gene encoding a Cloxalate transporter in patients with primary hyperparathyroidism. European Journal of Endocrinology, 160, 283-288. doi:10.1530/EJE-08-0623

[66] Wen, G., Wessel, J., Zhou, W., Ehret, G.B., Rao, F., Stridsberg, M., Mahata, S.K., Gent, P.M., Das, M., Cooper, R.S., Chakravarti, A., Zhou, H., Schork, N.J., O'Connor, D.T. and Hamilton, B.A. (2007) An ancestral variant of Secretogranin II confers regulation by PHOX2 transcription factors and association with hypertension. Human Molecular Genetics, 16, 1752-1764. doi: $10.1093 / \mathrm{hmg} / \mathrm{ddm} 123$

[67] Dries, D.L., Victor, R.G., Rame, J.E., Cooper, R.S., Wu, X., Zhu, X., Leonard, D., Ho, S.I., Wu, Q., Post, W. and Drazner, M.H. (2005) Corin gene minor allele defined by 2 missense mutations is common in blacks and associated with high blood pressure and hypertension. Circulation, 112, 2403-2410.

\section{doi:10.1161/CIRCULATIONAHA.105.568881}

[68] Wang, W., Liao, X., Fukuda, K., Knappe, S., Wu, F., Dries, D.L., Qin, J. and Wu, Q. (2008) Corin variant associated with hypertension and cardiac hypertrophy exhibits impaired zymogen activation and natriuretic peptide processing activity. Circulation Research, 103, 502508. doi:10.1161/CIRCRESAHA.108.177352

[69] Naganuma, T., Nakayama, T., Sato, N., Fu, Z., Soma, M., Aoi, N. and Usami, R. (2008) A haplotype-based casecontrol study examining human extracellular superoxide dismutase gene and essential hypertension. Hypertension Research, 31, 1533-1540. doi:10.1291/hypres.31.1533

[70] Manunta, P. and Bianchi, G. (2006) Pharmacogenomics and pharmacogenetics of hypertension: Update and perspectives - The adducin paradigm. Journal of the American Society of Nephrology, 17, S30-S35. doi:10.1681/ASN.2005121346

[71] Mandò, C., Antonazzo, P., Tabano, S., Zanutto, S., Pileri, P., Somigliana, E., Colleoni, F., Martinelli, A., Zolin, A., Benedetto, C., Marozio, L., Neri, I., Facchinetti, F., Miozzo, M. and Cetin, I. (2009) Angiotensin-converting enzyme and adducin-1 polymorphisms in women with preeclampsia and gestational hypertension. Reproductive Sciences, 16, 819-826. doi:10.1177/1933719109336612

[72] Cohn, H.I., Xi, Y., Pesant, S., Harris, D.M., Hyslop, T., Falkner, B. and Eckhart, A.D. (2009) G protein-coupled receptor kinase 2 expression and activity are associated with blood pressure in black Americans. Hypertension, 54, 71-76. doi:10.1161/HYPERTENSIONAHA.108.125955

[73] Yamada, Y., Matsuo, H., Segawa, T., Watanabe, S., Kato, K., Hibino, T., Yokoi, K., Ichihara, S., Metoki, N., Yoshida, H., Satoh, K. and Nozawa, Y. (2006) Assessment of the genetic component of hypertension. American Journal of Hypertension, 19, 1158-1165. doi:10.1016/j.amjhyper.2006.04.010

[74] Seasholtz, T.M., Wessel, J., Rao, F., Rana, B.K., Khandrika, S., Kennedy, B.P., Lillie, E.O., Ziegler, M.G., Smith, D.W., Schork, N.J., Brown, J.H. and O'Connor, D.T. (2006) Rho kinase polymorphism influences blood pressure and systemic vascular resistance in human twins: role of heredity. Hypertension, 47, 937-947. doi:10.1161/01.HYP.0000217364.45622.f0

[75] Murray, F., Patel, H.H., Suda, R.Y., Zhang, S., Thistlethwaite, P.A., Yuan, J.X. and Insel, P.A. (2007) Expression and activity of cAMP phosphodiesterase isoforms in pulmonary artery smooth muscle cells from patients with pulmonary hypertension: Role for PDE1. American Journal of Physiology-Lung Cellular and Molecular Physiology, 292, L294-L303. doi:10.1152/ajplung.00190.2006

[76] Lee, J., Kim, S., Kim, J., Jeong, M.H., Oh, Y. and Choi, K.C. (2006) Increased expression of renal aquaporin water channels in spontaneously hypertensive rats. Kidney and Blood Pressure Research, 29, 18-23. doi:10.1159/000092483

[77] Liaw, C.W., Lovenberg, T.W., Barry, G., Oltersdorf, T., Grigoriadis, D.E. and De Souza, E.B. (1996) Cloning and characterization of the human corticotropin-releasing 
factor-2 receptor complementary deoxyribonucleic acid. Endocrinology, 137, 72-77.

doi:10.1210/en.137.1.72

[78] Briscoe, R.J., Cabrera, C.L., Baird, T.J., Rice, K.C. and
Woods, J.H. (2000) Antalarmin blockade of corticotropin releasing hormone-induced hypertension in rats. Brain Research, 881, 204-207.

doi:10.1016/S0006-8993(00)02742-6 
Supplementary Table 1. Candidate Genes of hypertension in QTL on chromosomes.

\begin{tabular}{|c|c|c|c|c|c|}
\hline QTL & Markers & $\begin{array}{l}\text { Search } \\
\text { region (bp) }\end{array}$ & Total genes & $\begin{array}{l}\text { Candidate genes } \\
\text { (Essential and secondary) }\end{array}$ & $\begin{array}{l}\text { Candidate genes } \\
\text { within } 1.5 \mathrm{M} / \\
\text { polymorphic genes }\end{array}$ \\
\hline Bp95 & $\begin{array}{l}\text { D1UIA8, } \\
\text { D1Rat18 }\end{array}$ & $0-22,869,052$ & $\begin{array}{l}248 \text { total } \\
194 \text { known } \\
38 \text { novel } \\
16 \text { predicted }\end{array}$ & 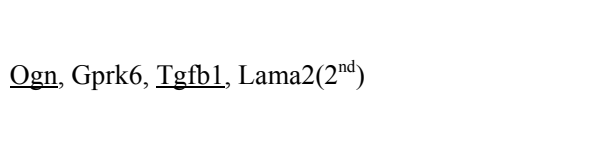 & $\mathrm{No} / 2$ \\
\hline Bp96 & $\begin{array}{l}\text { D1Mgh2, } \\
\text { D1Mit11 }\end{array}$ & $\begin{array}{l}22,842,962- \\
102,532,417\end{array}$ & $\begin{array}{l}1211 \text { total } \\
946 \text { known } \\
138 \text { novel }\end{array}$ & $\begin{array}{l}\text { Tgfb1 }, \text { Abcc } 8, \text { Apoe, } \operatorname{Kcnj11}, \operatorname{Abcc} 6\left(2^{\text {nd }}\right), \\
\text { Nphs1 }\left(2^{\text {nd }}\right), \operatorname{Akt} 2\left(2^{\text {nd }}\right), \operatorname{Ptgir}\left(2^{\text {nd }}\right), \text { Vip }, \operatorname{Sgk} 1, \operatorname{Trpm} 4, \\
\text { Sod2, Tph1, Axl, Slc22a2, Zfp260, Myadm Tctex } 1 \text {, } \\
\text { Boat1, Slc9a3 }\left(2^{\text {nd }}\right), \operatorname{Sdha}\left(2^{\text {nd }}\right)\end{array}$ & $\mathrm{No} / 5+1$ \\
\hline Bp173 & $\begin{array}{l}\text { D1Rat33 } \\
\text { D1Rat130 }\end{array}$ & $\begin{array}{l}115,946,375- \\
189,900,838\end{array}$ & $\begin{array}{l}954 \text { total } \\
772 \text { known, } \\
120 \text { novel } \\
62 \text { predicted }\end{array}$ & $\begin{array}{l}\text { 29. Iqgap } 1\left(2^{\text {nd }}\right), \text { Prc1, Fah, Plin, Ntrk3, Nr2f2, } \\
\text { Prcp, Nox } 4, \underline{S c n n 1 g, ~ N m b ~ C a p n 5}, \text { Anpep, Serpinh1, } \\
\left.\text { Pak1, Igf1r. Umod, Ucp2, Ucp3, Pde3b(2 } 2^{\text {nd, }}\right) \text {, spon } 1 \text {, } \\
\text { Inppl1, Phox2a, P2ry2, Scnn1b, Fgfr2, Sah, Xylt1, } \\
\text { Hbb, Acsm3 }\end{array}$ & $\mathrm{No} / 10$ \\
\hline Bp196 & $\begin{array}{l}\text { D1Mgh10, } \\
\text { D1Mgh1 }\end{array}$ & $\begin{array}{l}119,780,561- \\
204,280,279\end{array}$ & $\begin{array}{l}1146 \\
946 \text { known, } \\
128 \text { novel, } \\
172 \text { predicted }\end{array}$ & $\begin{array}{l}\text { Nox, Nmb, Capn5, Anpep, Serpinh1, Pak1, Fah, } \\
\text { Iqgap1 }\left(2^{\text {nd }}\right), \text { Prc1, Plin, Nr2f2, Igf1r } \\
\underline{\text { Scnn1b, Scnn1g, Fgfr2, Umod, Xylt1, Hbb, Prcp, }} \\
\text { Dhcr7, Th, Acsm3, Adm, }\end{array}$ & No./4 \\
\hline Bp255 & $\begin{array}{l}\text { D1Rat208, } \\
\text { D1Rat307 }\end{array}$ & $\begin{array}{l}195,927,908- \\
240,927,908\end{array}$ & $\begin{array}{l}915 \text { total } \\
749 \text { known } \\
66 \text { novel } \\
80 \text { predicted }\end{array}$ & $\begin{array}{l}\left.\text { Dhcr7, Th, Cyp17a1, Bbs1( } 2^{\text {nd }},\right) \text { Jak2, Gnaq, } \\
\text { Adrbk1, Ccnd1, Cyp2c23, Pax } 2\left(2^{\text {nd }}\right), C y p 2 e 1 \text {, } \\
\text { Kcnq1, Cpt1a, Gldc }\left(2^{\text {nd }}\right)\end{array}$ & Peak marker is NA. \\
\hline Bp259 & $\begin{array}{l}\text { D1Rat71, } \\
\text { D1Mgh12 }\end{array}$ & $\begin{array}{l}216,663,010- \\
247,322,280\end{array}$ & $\begin{array}{l}262 \text { total } \\
195 \text { known } \\
40 \text { novel } \\
27 \text { predicted }\end{array}$ & $\begin{array}{l}\text { Gldc }\left(2^{\text {nd }}\right) \text {, Pten, } \operatorname{Rbp} 4\left(2^{\text {nd }}\right), M b 12, K c n v 2, \text { Gna14, } \\
\text { Gnaq, Jak2 }\end{array}$ & $\begin{array}{l}\text { Rbp4: } \\
0.29 \mathrm{M} . / 1\end{array}$ \\
\hline Bp115 & $\begin{array}{l}\text { D2Uia17 } \\
\text { (peak) }\end{array}$ & $0-33,349,984$ & $\begin{array}{l}218 \text { total } \\
138 \text { known } \\
49 \text { novel } \\
31 \text { predicted }\end{array}$ & $\underline{\text { Cast }}$, Arts $1, \underline{\text { Thbs } 4}, \underline{\text { F2r }}, \operatorname{Pik} 3 r 1\left(2^{\text {nd }}\right)$, & No./3 \\
\hline Bp205 & $\begin{array}{l}\text { D2Rat73, } \\
\text { D2Mgh14 }\end{array}$ & $\begin{array}{l}26,101,089- \\
42,866,342\end{array}$ & $\begin{array}{l}109 \text { total } \\
80 \text { known } \\
19 \text { novel } \\
10 \text { predicted }\end{array}$ & No. & NA \\
\hline Bp14 & $\begin{array}{l}\text { D2Mgh12, } \\
\text { D2Mgh14 }\end{array}$ & $\begin{array}{l}42,866,342- \\
210,636,009\end{array}$ & $\begin{array}{l}1284 \text { total } \\
939 \text { known } \\
216 \text { novel } \\
129 \text { predicted }\end{array}$ & 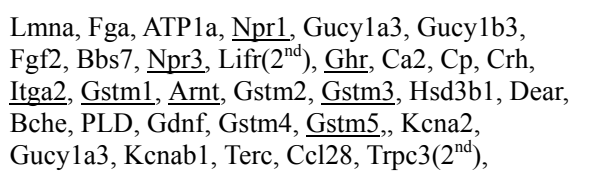 & $\begin{array}{l}\text { Peak marker is not } \\
\text { available/9 }\end{array}$ \\
\hline Bp203 & $\begin{array}{l}\text { D2Mit14, } \\
\text { D2Mgh29 }\end{array}$ & $\begin{array}{l}197,256,224- \\
227,310,008\end{array}$ & $\begin{array}{l}267 \text { Total } \\
210 \text { known } \\
34 \text { novel } \\
23 \text { predicted }\end{array}$ & $\begin{array}{l}\text { Edg1, Kcna10, Vcam1, F3, Gstm1, Gstm2, Gstm3, } \\
\text { Gstm4, Gstm5, Kcna2, }\end{array}$ & $\operatorname{Edg} 1(1.22 \mathrm{M}) / 0+1$ \\
\hline Bp175 & & $\begin{array}{l}222,939,299- \\
256,217,383\end{array}$ & $\begin{array}{l}220 \text { total } \\
155 \text { known } \\
35 \text { novel } \\
30 \text { predicted }\end{array}$ & $\begin{array}{l}\text { Cyr61, Edg7, } \\
\text { Mttp, Ddah1 }\end{array}$ & No. \\
\hline Bp15 & $\begin{array}{l}\text { D2Mgh12, } \\
\text { D2Mgh14 }\end{array}$ & $0-26,373,454$ & $\begin{array}{l}402 \text { total } \\
333 \text { known } \\
42 \text { novel } \\
27 \text { predicted }\end{array}$ & Dbh, Pax $8, \underline{\text { Kynu, }}$ Ptgs1 or COX1, Vav2, $\operatorname{I11r}\left(2^{\text {nd }}\right)$, & $\mathrm{No} / 1$ \\
\hline $\mathrm{Bp} 264$ & $\begin{array}{l}\text { D3Rat54, } \\
\text { D3Rat17 }\end{array}$ & $\begin{array}{l}10,267,753- \\
121,619,110\end{array}$ & $\begin{array}{l}1274 \text { total } \\
1039 \text { known } \\
146 \text { novel } \\
88 \text { predicted }\end{array}$ & $\begin{array}{l}\text { Ptgs } 1 \text { or COX } 1, \underline{\text { Kynu }}, \text { Avp, Nphp } 1\left(2^{\text {nd }}\right), \text { Cat, Bbs } 5 \text {, } \\
\text { Pcna }\left(2^{\text {nd }}\right), \underline{\text { Scn } 7 a}, \text { Dpp } 4, \text { Itgav }\end{array}$ & $\operatorname{Bbs} 5(1.27 \mathrm{M}) / 2+1$ \\
\hline
\end{tabular}




\section{Continued}

\begin{tabular}{|c|c|c|c|c|c|}
\hline Bp207 & $\begin{array}{l}\text { D3Mit49 } \\
\text { (Peak } \\
\text { marker) }\end{array}$ & $\begin{array}{l}111,188,559- \\
151,188,749\end{array}$ & $\begin{array}{l}495 \text { total } \\
391 \text { known } \\
67 \text { novel } \\
37 \text { predicted }\end{array}$ & $\operatorname{Jag} 1\left(2^{\text {nd }}\right), \operatorname{MKKS}\left(2^{\text {nd }}\right), \operatorname{Avp}$, Nphp1, Src, Illb, & $\begin{array}{l}\text { Peak marker is not } \\
\text { available } / 0+1\end{array}$ \\
\hline Bp81 & $\begin{array}{l}\text { D3Mgh2 } \\
\text { (peak } \\
\text { marker) }\end{array}$ & $\begin{array}{l}138,037,867- \\
178,038,027\end{array}$ & $\begin{array}{l}510 \text { total } \\
404 \text { known } \\
71 \text { novel } \\
35 \text { predicted }\end{array}$ & $\begin{array}{l}\operatorname{Src}\left(2^{\text {nd }}\right) \operatorname{Ptpn} 1, \operatorname{Hnf} 4 \mathrm{a}, \operatorname{Ada}\left(2^{\text {nd }}\right), \operatorname{Ahcy}\left(2^{\text {nd }}\right), \\
\operatorname{Hrh} 3\left(2^{\text {nd }}\right), \operatorname{Mmp} 9\left(2^{\text {nd }}\right), \operatorname{Myh} 7 \mathrm{~b} \_\operatorname{predicted}\left(2^{\text {nd }}\right)\end{array}$ & Ptpn1 ptgds (1.03M) \\
\hline Bp179 & $\begin{array}{l}\text { D4Rat12, } \\
\text { D4Mgh2 }\end{array}$ & $\begin{array}{l}6,178,308- \\
46,178,440\end{array}$ & $\begin{array}{l}239 \text { total } \\
159 \text { known } \\
61 \text { novel } \\
19 \text { predicted }\end{array}$ & $\begin{array}{l}\text { Nos } 3, \text { Hgf, } \operatorname{Cav}\left(2^{\text {nd }}\right), \text { Pon- } 1, \\
\text { Cftr( }\left(2^{\text {nd }}\right), \text { Pon- } 2, \text { ABCB } 1, \text { Colna2, Sema3a, } \\
\underline{\text { Lep }}\end{array}$ & $\mathrm{No} / 2$ \\
\hline Bp86 & $\begin{array}{l}\text { D4Mit2, } \\
\text { D4Mit11 }\end{array}$ & $\begin{array}{l}55,369,932- \\
91,330,856\end{array}$ & $\begin{array}{l}390 \text { total } \\
325 \text { known } \\
43 \text { novel } \\
22 \text { predicted }\end{array}$ & $\begin{array}{l}\text { 10+1. Lep, Npy, } \\
\text { Pde1c }\left(2^{\text {nd }}\right), \text { Trpv5, Aqp1, Crhr2, Hoxa9, } \\
\operatorname{Hoxa} 5\left(2^{\text {nd }}\right), \text { Casp2, Mtpn, Tbxas } 1\left(2^{\text {nd }}\right),\end{array}$ & $\begin{array}{l}\text { Peak marker is not } \\
\text { available } / 0+1\end{array}$ \\
\hline Bp124 & $\begin{array}{l}\text { D4Rat34 } \\
\text { (peak } \\
\text { marker) }\end{array}$ & $\begin{array}{l}65,014,032- \\
105,014,222\end{array}$ & $\begin{array}{l}456 \text { total } \\
294 \text { known } \\
124 \text { novel } \\
38 \text { predicted }\end{array}$ & $\begin{array}{l}\text { Npy, Pde1c, Trpv5, Aqp1, Crhr2, Hoxa9, Hoxa5, } \\
\text { Casp2, Cntnap2, Fabp1, }\end{array}$ & $\begin{array}{l}\operatorname{Pde} 1 \mathrm{c}(.077 \mathrm{M}) \\
\operatorname{Aqp} 1(.92 \mathrm{M}) \\
\operatorname{crhr} 2(1.17 \mathrm{M})\end{array}$ \\
\hline Bp209 & $\begin{array}{l}\text { D4Mgh12 } \\
\text { (peak } \\
\text { marker) }\end{array}$ & $\begin{array}{l}163,954,705- \\
203,954,820\end{array}$ & 251 total & Lrp6, Pded3a( $\left.2^{\text {nd }}\right), \underline{\text { Olr1 }}$ & $\mathrm{No} / 1$ \\
\hline Bp119 & $\begin{array}{l}\text { D5Mgh2 } \\
\text { (peak) }\end{array}$ & $0-37,517,235$ & $\begin{array}{l}214 \text { total } \\
192 \text { known } \\
40 \text { novel } \\
22 \text { predicted }\end{array}$ & Slc26a7, & No \\
\hline Bp254 & $\begin{array}{l}\text { D5Rat9, } \\
\text { D5Rat108 }\end{array}$ & $\begin{array}{l}61,080,143- \\
134,872,086\end{array}$ & $\begin{array}{l}506 \text { total } \\
371 \text { known } \\
90 \text { novel } \\
45 \text { predicted }\end{array}$ & $\underline{\text { Abca1 }}, \operatorname{Tek}\left(2^{\text {nd }}\right)$, Cyp2j4 & No/1 \\
\hline Bp147 & $\begin{array}{l}\text { D5Rat41(pe } \\
\text { ak marker) }\end{array}$ & $\begin{array}{l}135,450,641- \\
175,450,769\end{array}$ & $\begin{array}{l}744 \text { total } \\
606 \text { known } \\
89 \text { novel } \\
49 \text { predicted }\end{array}$ & $\begin{array}{l}\text { Ece1, Nppa, Tnfrsflb, Cda }\left(2^{\text {nd }}\right), \text { Slc9a1, Nppb, } \\
\left.\text { Uts2, Alpl, Cyp4a1, Slc2a5, Edn2( } 2^{\text {nd }}\right), \text { Tnfrsf4, } \\
\underline{\text { Fabp3 }} \text {, Guca2b, Ptpru, Clcnkb }\end{array}$ & No/6 \\
\hline $\begin{array}{l}\text { BpQTL } \\
\text { cluster7 }\end{array}$ & $\begin{array}{l}\text { D6Mit3, } \\
\text { D6Mit12( } \\
\text { D6Rat212 } \\
\text { flanking } \\
\text { marker) }\end{array}$ & $\begin{array}{l}14,873,099- \\
75,049,528\end{array}$ & $\begin{array}{l}372 \text { total } \\
255 \text { known } \\
69 \text { novel } \\
48 \text { predicted }\end{array}$ & $\begin{array}{l}\text { 9. Id2 (2nd }), \text { Apob, Ahr, Rock2, Slc26a4, Lpin1, } \\
\operatorname{Ucn}\left(2^{\text {nd }}\right), \underline{\text { Hpcal1 }}, \text { Emilin1 }\end{array}$ & $\begin{array}{l}\text { Peak marker is not } \\
\text { available/4 }\end{array}$ \\
\hline Bp211 & $\begin{array}{l}\text { D6Mit3, } \\
\text { D6Mit12 }\end{array}$ & $\begin{array}{l}75,049,528- \\
136,649,683\end{array}$ & $\begin{array}{l}715 \text { total } \\
443 \text { known } \\
102 \text { novel } \\
170 \text { predicted }\end{array}$ & $\begin{array}{l}\left.\text { Chga, Esr2, Yy1. Hif1 a(2 } 2^{\text {nd }}\right), \text { Bdkrb1, Arg2, Dio2, } \\
\text { Serpina1 }\left(2^{\text {nd }}\right), \underline{\text { Bdkrb2 }}\end{array}$ & $\begin{array}{l}\text { Peak marker is not } \\
\text { available/4 }\end{array}$ \\
\hline Bp182 & $\begin{array}{l}\text { D7Rat27, } \\
\text { D7Rat139 }\end{array}$ & $\begin{array}{l}32,004,505- \\
89,945,095\end{array}$ & $\begin{array}{l}351 \text { total } \\
2501 \text { known } \\
63 \text { novel } \\
38 \text { predicted }\end{array}$ & Nts, $\operatorname{Cdk} 4,\left(2^{\text {nd }}\right), \operatorname{Admr}\left(2^{\text {nd }}\right), \underline{\operatorname{Lrp} 1}$ & No/1 \\
\hline Bp181 & $\begin{array}{l}\text { D7Rat73, } \\
\text { D7Rat133 }\end{array}$ & $\begin{array}{l}57,326,197- \\
109,727,159\end{array}$ & $\begin{array}{l}338 \text { total } \\
240 \text { known } \\
56 \text { known } \\
42 \text { predicted }\end{array}$ & $\begin{array}{l}\operatorname{Cdk} 4\left(2^{\text {nd }}\right), \operatorname{Admr}\left(2^{\text {nd }}\right), \underline{\operatorname{Lrp} 1}, \operatorname{Myc}, \operatorname{Ndrg} 1 . \underline{\operatorname{Trhr}}, \\
\text { Angpt1, Gpr }\left(2^{\text {nd }}\right),\end{array}$ & No/1+1 \\
\hline Bp214 & $\begin{array}{l}\text { D7Rat135 } \\
\text { (Peak) }\end{array}$ & $\begin{array}{l}88,021,524- \\
128,021,684\end{array}$ & $\begin{array}{l}490 \text { total } \\
399 \text { known } \\
47 \text { novel } \\
44 \text { predicted }\end{array}$ & $\begin{array}{l}\text { Ndrg1, } \\
\left.\text { cyt11b1, cyt11b2, Ppara, Pdgfb(2 } 2^{\text {nd }}\right) \\
\text { Commd5, Mb, Adm2 }\left(2^{\text {nd }}\right) \text {, Naga, Ptk2 }\end{array}$ & No/ \\
\hline Bp183 & $\begin{array}{l}\text { D7Rat13, } \\
\text { D7Rat80 }\end{array}$ & $\begin{array}{l}124,315,013- \\
141,301,748\end{array}$ & $\begin{array}{l}248 \text { total } \\
206 \text { known } \\
27 \text { novel } \\
15 \text { predicted }\end{array}$ & $\operatorname{Adm} 2\left(2^{\text {nd }}\right), \operatorname{Acvrl1}\left(2^{\text {nd }}\right), \operatorname{Sp} 1, \operatorname{Vdr}, \operatorname{Aqp} 2$ & $\begin{array}{l}\text { Acvrl1 } \\
(1.43 \mathrm{M}) \\
\mathrm{Sp} 1 \\
(0.14 \mathrm{M}) / 0\end{array}$ \\
\hline
\end{tabular}




\section{Continued}

\begin{tabular}{|c|c|c|c|c|c|}
\hline Bp262 & $\begin{array}{l}\text { D8Rat164 } \\
\text { (D8Rat190), } \\
\text { D8Mgh3 }\end{array}$ & $\begin{array}{l}28,124,112- \\
103,684,785\end{array}$ & $\begin{array}{l}849 \text { total } \\
669 \text { known } \\
102 \text { novel } \\
78 \text { predicted }\end{array}$ & $\begin{array}{l}\left.\text { Kcnj1, Hmbs( } 2^{\text {nd }}\right), \text { Atm, Cyp1a1 }, \text { Cyp1a2, Drd2, } \\
\text { Gclc, Rab27a, Rdx, Htr1b, }\end{array}$ & $\begin{array}{l}\text { Peak marker is not } \\
\text { available/3 }\end{array}$ \\
\hline Bp184 & $\begin{array}{l}\text { D8Rat114, } \\
\text { D8Rat2 }\end{array}$ & $\begin{array}{l}74,281,611- \\
123,415,406\end{array}$ & 483 total & Gclc, Rab27a, Trf, Slc26a6, Pthr1, Gnai2, & No./1 \\
\hline BP263 & $\begin{array}{l}\text { NA or } \\
\text { (D8Rat19, } \\
\text { D8Rat171) } \\
\text { or use } \\
\text { D8Rat116, } \\
\text { 128303883. }\end{array}$ & $\begin{array}{l}98,451,122- \\
127,956,046 \\
(127,955,981)\end{array}$ & 357 total & Trf, $\underline{\text { Slc26a6 }}$, Pthr1, Gnai2, Cx3cr1(2 $\left.2^{\text {nd }}\right)$ & $\begin{array}{l}\text { Peak marker is not } \\
\text { available/ } 0+1\end{array}$ \\
\hline Bp34 & $\begin{array}{l}\text { D9Uia6, } \\
\text { D9Uia9 }\end{array}$ & $\begin{array}{l}39,390,033- \\
77,170,798\end{array}$ & $\begin{array}{l}311 \text { total } \\
243 \text { known } \\
43 \text { novel } \\
25 \text { predicted }\end{array}$ & $\begin{array}{l}\text { Bmpr2 }\left(2^{\text {nd }}\right), \text { Fn1, Cps1, Ctla4 }, \text { Igfbp2, Casp } 8\left(2^{\text {nd }}\right) \text {, } \\
\text { Hspd1, }\end{array}$ & No./1 \\
\hline Bp185 & $\begin{array}{l}\text { D9Rat16, } \\
\text { D9Rat108 }\end{array}$ & $\begin{array}{l}70,696,863- \\
110,697,021\end{array}$ & $\begin{array}{l}343 \text { total } \\
277 \text { known } \\
32 \text { novel } \\
34 \text { predicted }\end{array}$ & $\begin{array}{l}\text { Fn1, Igfbp2, Htr2b }\left(2^{\text {nd }}\right), \text { Mlk, Ramp1, Col4a4, } \\
\text { Scg2 } \text { Nppc }\end{array}$ & $\begin{array}{l}\text { Ramp1 } \\
(0.29 \mathrm{M}) / 1\end{array}$ \\
\hline Bp57 & $\begin{array}{l}\text { D10Mit5, } \\
\text { D10Rat20 }\end{array}$ & $\begin{array}{l}21,607,720- \\
84,443,858\end{array}$ & $\begin{array}{l}1026 \text { total } \\
859 \text { known } \\
97 \text { novel } \\
70 \text { predicted }\end{array}$ & $\begin{array}{l}\text { Shbg, Nos2, CD68, Cc12, Trpv2, Adra1b, Tbx2, } \\
\text { Alox12, Atp1b2, Cias1, Il12b, }\end{array}$ & No./4 \\
\hline Bp168 & $\begin{array}{l}\text { D10Mit10, } \\
\text { D10Mco6 }\end{array}$ & $\begin{array}{l}27,184,742- \\
102,587,587\end{array}$ & $\begin{array}{l}1398 \text { total } \\
1182 \text { known } \\
122 \text { novel } \\
94 \text { predicted }\end{array}$ & $\begin{array}{l}\text { Wnk4, Ramp2(2nd }{ }^{\text {nd }}, \text { Xylt2 }\left(2^{\text {nd }}\right) \text {, Nos2, Ace, CD } 68 \text {, } \\
\text { Gip, Cc12, Trpv2, Adra1b, Apoh, Gh1, Crhr1, } \\
\frac{\text { Slc4a1, Tbx2, Alox12, Cias1, Il12b, Atp2a3, Ser }}{\text { pinf2, }}\end{array}$ & $\begin{array}{l}\text { Peak marker is not } \\
\text { available/2 }\end{array}$ \\
\hline Bp186 & $\begin{array}{l}\text { *D10Rat17, } \\
\text { D10Rat2 }\end{array}$ & $\begin{array}{l}95,066,219- \\
110,718,848\end{array}$ & $\begin{array}{l}263 \text { total } \\
217 \text { known } \\
28 \text { novel } \\
18 \text { predicted }\end{array}$ & Ace, Gh1, Tmp2(2 $\left.{ }^{\text {nd }}\right), \operatorname{Sstr} 2\left(2^{\text {nd }}\right)$, Uts 2 r2 & $\begin{array}{l}\text { Peak marker is not } \\
\text { available }\end{array}$ \\
\hline Bp187 & $\begin{array}{l}\text { D11Rat15 } \\
\text { (peak) }\end{array}$ & $\begin{array}{l}9,053,659- \\
50,435,443\end{array}$ & $\begin{array}{l}296 \text { total } \\
214 \text { known } \\
51 \text { novel } \\
31 \text { predicted }\end{array}$ & $\begin{array}{l}\text { Arl6 }\left(2^{\text {nd }}\right) \\
\text { Sod1, }\end{array}$ & No \\
\hline $\begin{array}{l}\text { BpQTLc } \\
\text { luster10 }\end{array}$ & $\begin{array}{l}\text { D11Mit1, } \\
\text { D11Mit5 }\end{array}$ & $\begin{array}{l}35,910,590- \\
80,910,590\end{array}$ & $\begin{array}{l}406 \text { total } \\
310 \text { known } \\
66 \text { novel } \\
30 \text { predicted }\end{array}$ & $\begin{array}{l}\text { Arl6 }\left(2^{\text {nd }}\right), \text { Casr, Mylk, } \\
\text { Drd } 3 .\end{array}$ & $\begin{array}{l}\text { Peak marker is not } \\
\text { available/1 }\end{array}$ \\
\hline Bp294 & $\begin{array}{l}\text { D12Mit6 } \\
\text { (peak) }\end{array}$ & $0-32,770,333$ & $\begin{array}{l}480 \text { total } \\
361 \text { known } \\
62 \text { novel } \\
57 \text { predicted }\end{array}$ & $\begin{array}{l}\left.\text { Retn, Kl, Prkar1b, Eln, Pdgfa( } 2^{\text {nd }}\right), \text { Gna12, Rac1, } \\
\text { Insr, Slc7a1, Pdgfa }\left(2^{\text {nd }}\right)\end{array}$ & $\begin{array}{l}\operatorname{Rac} 1 \\
(0.89 \mathrm{M}) / 2\end{array}$ \\
\hline Bp218 & $\begin{array}{l}\text { D12Mgh5 } \\
\text { (peak) }\end{array}$ & $\begin{array}{l}9,130,181- \\
49,130,304\end{array}$ & $\begin{array}{l}553 \text { total } \\
469 \text { known } \\
52 \text { novel' } \\
32 \text { predicted }\end{array}$ & Pla2g1b, Eln, Gna12, Rac1, Aldh2, Nos1, & No/1+1 \\
\hline Bp222 & $\mathrm{D} 13 \mathrm{Mgh} 4$ & $\begin{array}{l}18,489,802- \\
58,489,943\end{array}$ & $\begin{array}{l}261 \text { total } \\
189 \text { known } \\
42 \text { novel } \\
30 \text { predicted }\end{array}$ & $\underline{\text { Rgs2}}$, Adipor1, Il10, Ren1, Adora1, & $\mathrm{No} / 2$ \\
\hline Bp241 & $\begin{array}{l}\text { D13Arb5- } \\
\text { D13Rat163 }\end{array}$ & $\begin{array}{l}38,985,718- \\
105,788,017\end{array}$ & $\begin{array}{l}681 \text { total } \\
525 \text { known } \\
99 \text { novel } \\
57 \text { predicted }\end{array}$ & $\begin{array}{l}\text { Sele, Rgs5, Fmo3, Rgs2, Atp1b1, F5, Adipor1, } \\
\text { Atp1a2, Tnfsf4, F11r, Ptgs2, Adora1, Serpinc1. }\end{array}$ & $\begin{array}{l}\text { Peak marker is not } \\
\text { available/ } 7+1\end{array}$ \\
\hline Bp189 & $\begin{array}{l}\text { D14Rat10, } \\
\text { D14Rat90 }\end{array}$ & $\begin{array}{l}33,157,433- \\
73,956,701\end{array}$ & $\begin{array}{l}245 \text { total } \\
166 \text { known } \\
53 \text { novel } \\
76 \text { predicted }\end{array}$ & $\underline{\text { Corin, }}, \underline{\text { Sod3 }}$, Med28, & No./2 \\
\hline
\end{tabular}




\section{Continued}

\begin{tabular}{|c|c|c|c|c|c|}
\hline Bp59 & $\begin{array}{l}\text { D14Rat90, } \\
\text { D14Rat94 }\end{array}$ & $\begin{array}{l}73,956,597- \\
89,192,873\end{array}$ & $\begin{array}{l}214 \text { total } \\
173 \text { known } \\
19 \text { novel } \\
22 \text { predicted }\end{array}$ & $\begin{array}{l}\text { Drd5, Fgfr3 }\left(2^{\text {nd }}\right), \text { Add1, Grk4(Gprk21, Igfbp } 3\left(2^{\text {nd }}\right) \text {, } \\
\text { Gck. }\end{array}$ & $\begin{array}{l}\text { Add1 } \\
(0 \mathrm{M}), / 3\end{array}$ \\
\hline Bp191 & $\begin{array}{l}\text { D15Rat114, } \\
\text { D15Rat75 }\end{array}$ & $0-14,323,976$ & $\begin{array}{l}118 \text { total } \\
81 \text { known } \\
30 \text { novel } \\
7 \text { predicted }\end{array}$ & No & No. \\
\hline $\begin{array}{l}\text { Bp191 } \\
\text { (use } \\
\text { flanking } \\
\text { marker) }\end{array}$ & $\begin{array}{l}\text { D15Rat57, } \\
\text { D15Rat75 }\end{array}$ & $\begin{array}{l}9,376,539- \\
14,324,114\end{array}$ & $\begin{array}{l}34 \text { total } \\
19 \text { known } \\
10 \text { novel } \\
5 \text { predicted }\end{array}$ & $\operatorname{Ednrb}\left(2^{\text {nd }}\right)$ & $\begin{array}{l}\text { Peak marker is not } \\
\text { available }\end{array}$ \\
\hline Bp126 & $\begin{array}{l}\text { Ednrb } \\
\text { (peak } \\
\text { marker) }\end{array}$ & $\begin{array}{l}67,893,681- \\
107,893,681\end{array}$ & $\begin{array}{l}158 \text { total } \\
95 \text { known } \\
36 \text { novel } \\
27 \text { predicted }\end{array}$ & $\operatorname{Ednrb}\left(2^{\text {nd }}\right)$ & Ednrb (0 M) \\
\hline Bp190 & $\begin{array}{l}\text { D15Mgh9, } \\
\text { D15Rat106 }\end{array}$ & $\begin{array}{l}89,569,707- \\
106,177,917\end{array}$ & $\begin{array}{l}57 \text { total } \\
37 \text { known } \\
13 \text { novel } \\
7 \text { predicted }\end{array}$ & $\operatorname{Ednrb}\left(2^{\text {nd }}\right)$ & No. \\
\hline $\begin{array}{l}\text { BpQTLc } \\
\text { luster13 }\end{array}$ & $\begin{array}{l}\text { Glud1 } \\
\text { (peak) }\end{array}$ & $\begin{array}{l}4,304,397- \\
46,137,590\end{array}$ & $\begin{array}{l}400 \text { total } \\
287 \text { known } \\
70 \text { novel } \\
43 \text { predicted }\end{array}$ & Glud1, Lpl, Prkcd, Nisch, Mapk8, NPY1R & $\begin{array}{l}\text { Glud1 } \\
(0 \mathrm{M}) \\
\text { Mapk8 } \\
(1.04 \mathrm{M}) / 1\end{array}$ \\
\hline Bp247 & D17Rat102 & $\begin{array}{l}7,118,352- \\
47,118,575\end{array}$ & $\begin{array}{l}356 \text { total } \\
282 \text { known } \\
49 \text { novel } \\
25 \text { predicted }\end{array}$ & Agtr1a, Drd1a, Edn1, Ogn, Prl & $\begin{array}{l}\text { Edn1 } \\
(1.19 \mathrm{M}) / 1\end{array}$ \\
\hline Bp242 & $\begin{array}{l}\text { D17Rat98 } \\
\text { (peak) }\end{array}$ & $\begin{array}{l}44,047,700- \\
84,047,886\end{array}$ & $\begin{array}{l}336 \text { total } \\
239 \text { known } \\
69 \text { novel } \\
28 \text { predicted }\end{array}$ & Mtr, Prl & No \\
\hline Bp192 & $\begin{array}{l}\text { D17Rat16, } \\
\text { D17Rat47 }\end{array}$ & $\begin{array}{l}54,663,819- \\
94,663,991\end{array}$ & $\begin{array}{l}280 \text { total } \\
194 \text { known } \\
61 \text { novel } \\
25 \text { predicted }\end{array}$ & Mtr & No \\
\hline Bp2 & D18Mit7 & $0-33,239,845$ & $\begin{array}{l}282 \text { total } \\
228 \text { known } \\
23 \text { novel } \\
31 \text { predicted }\end{array}$ & $\mathrm{Nr} 3 \mathrm{c} 1, \underline{\text { Rock }}$ & No/1 \\
\hline Bp233 & D18Rat57 & $\begin{array}{l}34,605,733- \\
74,605,912\end{array}$ & $\begin{array}{l}319 \text { total } \\
245 \text { known } \\
42 \text { novel } \\
32 \text { predicted }\end{array}$ & $\begin{array}{l}\text { Mex3c, Adrb2, Acaa2, Hsd17b4, Slc12a, Lox, } \\
\text { Pdgfrb Nr3c1, Lipg }\end{array}$ & $\begin{array}{l}\text { Slc12a } \\
(0.93 \mathrm{M}) / 2+1\end{array}$ \\
\hline Bp48 & $\begin{array}{l}\text { Flak } \\
\text { D18Mit9 } \\
\text { (D18Mit6) }\end{array}$ & $\begin{array}{l}63,595,606- \\
82,920,380\end{array}$ & $\begin{array}{l}128 \text { total } \\
89 \text { known } \\
21 \text { novel } \\
12 \text { predicted }\end{array}$ & $\begin{array}{l}\text { Mex3c, Acaa2, } \\
\text { Lipg }\end{array}$ & $\begin{array}{l}\text { Peak marker is not } \\
\text { available }\end{array}$ \\
\hline Bp195 & $\begin{array}{l}\text { D20UW1, } \\
\text { D20Rat2 }\end{array}$ & $\begin{array}{l}3,660,639- \\
9,534,496\end{array}$ & $\begin{array}{l}179 \text { total } \\
162 \text { known } \\
12 \text { novel } \\
5 \text { predicted }\end{array}$ & Tnf, Tap1, Glp1r, Cdkn1a (2 $\left.2^{\text {nd }}\right)$, & $\begin{array}{l}\operatorname{Tnf}(0.000362 \mathrm{M}) \\
\text { Tap1 }(1.13 \mathrm{M}) / 1\end{array}$ \\
\hline Bp60 & $\begin{array}{l}\text { D20Rat40 } \\
\text { (peak) }\end{array}$ & $\begin{array}{l}13,791,487- \\
53,791,685\end{array}$ & $\begin{array}{l}290 \text { total } \\
211 \text { known, } \\
47 \text { novel } \\
32 \text { predicted }\end{array}$ & 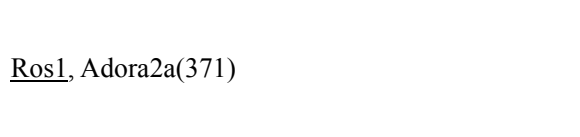 & No/1 \\
\hline Bp65 & $\begin{array}{l}\text { DXRat4(pe } \\
\text { ak marker) }\end{array}$ & $\begin{array}{l}3,494,725- \\
43,494,887\end{array}$ & 373 total & Rhoa, Trpc5, Timp1 & No \\
\hline Bp56 & $\begin{array}{l}\text { DXMgh9, } \\
\text { DXMit4 }\end{array}$ & $\begin{array}{l}79,626,109- \\
88,514,169\end{array}$ & 79 total & $\underline{\operatorname{Ar}}\left(, \operatorname{Cybb}\left(2^{\text {nd }}\right)\right.$ & No/1 \\
\hline
\end{tabular}

